\section{PEPPERDINE \\ UNIVERSITY}

Journal of the National Association of Administrative Law Judiciary

$10-15-2010$

\title{
Ordinary Administrative Law as Constitutional Common Law
}

Gillian E. Metzger

Follow this and additional works at: https://digitalcommons.pepperdine.edu/naalj

Part of the Administrative Law Commons, Constitutional Law Commons, and the Judges Commons

\section{Recommended Citation}

Gillian E. Metzger, Ordinary Administrative Law as Constitutional Common Law, $30 \mathrm{~J}$. Nat'l Ass'n Admin. L. Judiciary Iss. 2 (2010)

Available at: https://digitalcommons.pepperdine.edu/naalj/vol30/iss2/2

This Article is brought to you for free and open access by the Caruso School of Law at Pepperdine Digital Commons. It has been accepted for inclusion in Journal of the National Association of Administrative Law Judiciary by an authorized editor of Pepperdine Digital Commons. For more information, please contact bailey.berry@pepperdine.edu. 


\title{
Ordinary Administrative Law as Constitutional Common Law*
}

\author{
By Gillian E. Metzger**
}

\section{INTRODUCTION}

Much has changed in constitutional law since 1975 when Henry Monaghan published his Harvard Law Review Foreword on Constitutional Common Law. ${ }^{1}$ Whole areas of doctrine have been born - and in some cases died. ${ }^{2}$ Yet Constitutional Common Law remains remarkably au courant. Indeed, it presaged several of the central themes in constitutional law scholarship over the last decade, such as the role of the political branches and popular movements in constitutional interpretation or the relationship of constitutional

* This article was originally published by the Columbia University Law Review in 2010 and can be located at 110 Colum. L. Rev. 479 (2010). J. NAALJ obtained permission to reprint this article both from the Columbia University Law Review and the author.

** Professor of Law, Columbia Law School. Special thanks to Mitchell Berman, Ariela Dubler, Joseph Landau, Trevor Morrison, Nate Persily, Jim Pfander, Peter Strauss - and, above all, Henry Monaghan. This Essay also benefitted from helpful comments at Northwestern University Law School's Constitutional Law Colloquium. Esha Bhandari and the staff of the Columbia Law Review provided excellent editorial assistance.

${ }^{1}$ Henry P. Monaghan, The Supreme Court, 1974 Term - Foreword: Constitutional Common Law, 89 Harv. L. Rev. 1 (1975) [hereinafter Monaghan, Constitutional Common Law].

${ }^{2}$ Contemporary constitutional doctrine allowing limits on campaign contributions, for example, was crystallized in 1976 with the Court's decision in Buckley v. Valeo, 424 U.S. 1 (1976), but now seems headed for significant curtailment, if not extinction. See Randall v. Sorrell, 548 U.S. 230, 262-65 (2006) (invalidating contribution and expenditure limits at issue, with several concurring opinions raising questions about the continued viability of the Buckley framework). The extensive constitutional case law on the use of race in affirmative action has also grown up in this period, starting with Regents of the University of California $v$. Bakke, 438 U.S. 265 (1978). 
doctrine to constitutional meaning. ${ }^{3}$ More importantly, the practice of constitutional common law continues to this day and so too does the debate over its legitimacy.

By constitutional common law Monaghan referred to "a substructure of substantive, procedural, and remedial rules drawing their inspiration and authority from, but not required by, various constitutional provisions... [and] subject to amendment, modification, or even reversal by Congress." 4 Such common law rules, he argued, represent "a surprising amount of what passes as authoritative constitutional 'interpretation'" - a feature of our constitutional practice obscured by the "mystique surrounding Marbury v. Madison"5 and the Marbury view of the Court as the "authoritative and final" determiner of constitutional meaning. ${ }^{6}$ Monaghan gave several examples of this phenomenon, moving from structural matters like the dormant Commerce Clause to individual liberties, most famously some of the Court's seminal criminal procedure rulings such as the warnings required under Miranda v. Arizona. ${ }^{7}$ In each of these

${ }^{3}$ The scholarship on each of these topics is extensive, so the following list makes no attempt to be comprehensive. For discussions of the role of the political branches and social movements in constitutional interpretation, see Larry D. Kramer, The People Themselves: Popular Constitutionalism and Judicial Review (2004); Keith E. Whittington, Constitutional Construction: Divided Powers and Constitutional Meaning (1999); Robert Post \& Reva Siegel, Popular Constitutionalism, Departmentalism, and Judicial Supremacy, 92 Cal. L. Rev. 1027 (2004) [hereinafter Post \& Siegel, Popular Constitutionalism]; Larry Alexander \& Lawrence B. Solum, Popular? Constitutionalism?, 118 Harv. L. Rev. 1594 (2005) (book review). For discussions of the relationship between constitutional doctrine and constitutional meaning, see Richard H. Fallon, Jr., Implementing the Constitution (2001) [hereinafter Fallon, Implementing]; Mitchell N. Berman, Constitutional Decision Rules, 90 Va. L. Rev. 1 (2004); Kermit Roosevelt III, Constitutional Calcification: How the Law Becomes What the Court Does, $91 \mathrm{Va}$. L. Rev. 1649 (2005); David A. Strauss, The Ubiquity of Prophylactic Rules, $55 \mathrm{U}$. Chi. L. Rev. 190 (1988) [hereinafter Strauss, Prophylactic Rules].

${ }^{4}$ Monaghan, Constitutional Common Law, supra note 1, at 2-3.

${ }^{5}$ Id. at 2 (citing 5 U.S. (1 Cranch) 137 (1803)).

${ }^{6}$ Id.

${ }^{7} 384$ U.S. 436, 467-68 (1966); Monaghan, Constitutional Common Law, supra note 1 , at 3-26. 
contexts, the Court expressly acknowledged that its constitutional rulings were to some extent revisable by Congress. ${ }^{8}$

From the outset, some scholars have condemned constitutional common law as illegitimate judicial lawmaking or, alternatively, as insufficiently protective of constitutional rights. ${ }^{9}$ Indeed, the Court itself was notably ambivalent about Congress's ability to revise judicial constitutional determinations. ${ }^{10}$ Over the years, the Court has become more reluctant to characterize its constitutional rulings as contingent or acknowledge a robust role for Congress in constitutional individual rights interpretation. The 2001 decision in Dickerson v. United States is a prime exemplar of this trend: While not insisting that "the Miranda warnings are required by the Constitution, in the sense that nothing else will suffice to satisfy constitutional requirements," the Court in Dickerson concluded that the Miranda warnings represented a constitutional rule binding on

${ }^{8}$ See Illinois v. City of Milwaukee, 406 U.S. 91, 107 (1972) ("It may happen that new federal laws ... may in time pre-empt the field of federal common law of nuisance."); Miranda, 384 U.S. at 467 (acknowledging Congress may devise "potential alternatives" to Court's Miranda warnings); Prudential Ins. Co. v. Benjamin, 328 U.S. 408, 425 (1946) (noting Court has sustained congressional action "contradicting the Court's previously expressed view that specific action taken by the states in Congress' silence was forbidden by the commerce clause"); Monaghan, Constitutional Common Law, supra note 1, at 11, 20, 27-30 ("Where the Court's rule is perceived to have gone too far, it can be rejected or modified by the political process without the necessity of a constitutional amendment."); see also Bush v. Lucas, 462 U.S. 367, 389-90 (1983) (post-"Constitutional Common Law" decision bearing out Monaghan's prediction that congressional actions may determine whether a Bivens action will lie).

${ }^{9}$ See infra text accompanying notes 125-129. Indeed, some scholars have rejected Monaghan's claims that these decisions represent constitutional common law at all. See, e.g., Joseph D. Grano, Prophylactic Rules in Criminal Procedure: A Question of Article III Legitimacy, 80 Nw. U. L. Rev. 100, 119-22 (1985) (arguing that constitutional common law includes rules that "seem[] to be of the pure Marbury variety," including rules with respect to the right to counsel); Thomas S. Schrock \& Robert C. Welsh, Reconsidering The Constitutional Common Law, 91 Harv. L. Rev. 1117, 1138-40 (1978) (rejecting argument that Congress's power to authorize dormant Commerce Clause violations is an instance of constitutional common law).

${ }^{10}$ See, e.g., Katzenbach v. Morgan, 384 U.S. 641, 651 n.10, 652-56 (1966) (upholding congressional prohibition on many English literacy voting qualifications but noting that Congress lacks power to dilute judicially determined constitutional protections). 
Congress, at least to the extent of necessitating invalidation of a congressional statute that the Court characterized as intended to overrule Miranda. ${ }^{11}$ Similarly indicative is the Court's greater scrutiny of congressional enactments under Section 5 of the Fourteenth Amendment and its insistence in that context on Marburystyle judicial review with the Court as the supreme arbiter of constitutional meaning. ${ }^{12}$ Significantly, the Court also has not identified a role for Congress when expanding the scope of constitutional protections, thus signaling that its reluctance to involve Congress is not simply a reflection of a narrower view of the constitutional rights involved. ${ }^{13}$

11530 U.S. $428,437-43(2000)$. Dickerson is ambiguous as to whether a congressional effort to replace the Miranda wamings would be constitutionally acceptable, limiting itself to noting that the substitute Congress enacted, a totality of the evidence analysis, was not adequate and was rejected by the Court in Miranda itself. Id. at 441-43. Even so, the Court's characterization of the warnings as a constitutional rule contrasts notably with its earlier, post-Miranda precedent that described the warnings as not constitutionally mandated, and with other decisions more overtly acknowledging a role for the political branches. See id. at 450-54 (Scalia, J., dissenting) (describing and quoting from intervening decisions stating the Miranda warnings were not constitutionally protected); see also Smith $v$. Robbins, 528 U.S. 259, 265 (2000) (describing Anders rule for when appointed counsel have fulfilled their duties of representation on appeal as a "prophylactic rule" and stating that "states are free to adopt different procedures, so long as those procedures adequately safeguard a defendant's right to appellate counsel"); Roosevelt, supra note 3, at 1668-72 (discussing Dickerson and Smith).

${ }^{12}$ See City of Boerne v. Flores, 521 U.S. 507, 519, 536 (1997) (stating that Congress's power "extends only to 'enforcing' the provisions of the Fourteenth Amendment," not to determining "what constitutes a constitutional violation," and that "the courts retain the power, as they have since Marbury v. Madison, to determine if Congress has exceeded its authority under the Constitution" (alteration in original)); see also Bd. of Trs. of the Univ. of Ala. v. Garrett, 531 U.S. 356, 374 (2001) (holding "Congress is the final authority as to desirable public policy," but cannot "rewrite the Fourteenth Amendment law laid down by this Court").

${ }^{13}$ See, e.g., District of Columbia v. Heller, 128 S. Ct. 2783, 2816-17 (2008) (making no reference to a congressional role in defining scope of Second Amendment right to possess a gun for self-defense in the home, other than noting that longstanding prohibitions on firearms possession were not being called into question); Crawford v. Washington, 541 U.S. 36, 42-65 (2004) (making no reference to alternative rules Congress or the states could adopt in holding Confrontation Clause bars testimonial out-of-court statements by witnesses). The closest the Court has come to acknowledging an implementation role for the political branches (state as well as federal) was its recent decision in Melendez- 
Yet the Court's resistance to acknowledging constitutional interpretive plurality has not spelled the end of constitutional common law. One area in which constitutional common law remains particularly prevalent, though largely unrecognized as such, is ordinary administrative law. ${ }^{14}$ Administrative law is generally understood as having constitutional as well as what I will call "ordinary law" components - with ordinary law here referring to statutory and regulatory requirements, such as the Administrative Procedure Act (APA) ${ }^{15}$ or Executive Order $12,866^{16}$ and associated administrative law doctrines. ${ }^{17}$ What is less often acknowledged,

Diaz v. Massachusetts, 129 S. Ct. 2527, 2540-42 (2009), in which it noted with seeming approval state notice-and-demand statutes as a mechanism for meeting the demands of the Confrontation Clause. See also Jennifer B. Sokoler, Note, Between Substance and Procedure: A Role for States' Interests in the Scope of the Confrontation Clause, 110 Colum. L. Rev. 161 (2010). In another decision last term, Corley v. United States, 129 S. Ct. 1558, 1562 (2009), the Court accepted without discussion Congress's power to limit the Court's McNabb-Mallory doctrine excluding confessions made during periods of unreasonable delay before presentment to a judge, but this reflected the understanding of McNabb-Mallory as an exercise of the Court's supervisory power over the federal courts rather than a constitutionally mandated requirement that would apply to state courts as well.

${ }^{14}$ Many of Monaghan's specific examples remain good law as well, particularly those involving constitutional structure, such as the dormant Commerce Clause and interstate water pollution. See Richard H. Fallon, Jr. et al., Hart and Wechsler's The Federal Courts and the Federal System 660-63 (6th ed. 2009) [hereinafter Hart and Wechsler] (recognizing power of federal courts to make common law in dormant Commerce Clause context); see also Gillian E. Metzger, Congress, Article IV and Interstate Relations, 120 Harv. L. Rev. 1468 , 1480-85 (2007) (describing Congress's power to authorize state violations of the dormant Commerce Clause). Recent decisions on Bivens actions all fall into the constitutional common law mold, although the Court's Bivens jurisprudence also reveals substantial retrenchment in the availability of Bivens actions. Hart and Wechsler, supra, at 733-42. Perhaps the most frequent instance of constitutional common law today, however, is application of the constitutional canons in statutory interpretation. See infra text accompanying notes 135-137.

155 U.S.C. $\$ 551$ et seq. (2006).

${ }^{16} 3$ C.F.R. 638 (1993), reprinted as amended in 5 U.S.C. $\S 601$ (2006).

${ }^{17}$ See, e.g., Motor Vehicle Mfrs. Ass'n v. State Farm Mut. Auto. Ins. Co., 463 U.S. 29, 42-44 (1983) (explicating meaning of APA's "arbitrary and capricious" standard); see also Lisa Schultz Bressman, Beyond Accountability: Arbitrariness and Legitimacy in the Administrative State, 78 N.Y.U. L. Rev. 461, 463-64 (2003) [hereinafter Bressman, Beyond Accountability] (distinguishing between ordinary administrative law and constitutional administrative law). 
especially by courts, is the degree to which constitutional concerns permeate ordinary administrative law, in particular doctrines of judicial review of agency action. A striking example of this lack of acknowledgment is the 2009 decision in FCC v. Fox Television Stations, Inc., in which the Court expressly refused to link ordinary administrative law to constitutional concerns. ${ }^{18}$

Fox involved a challenge to the FCC's new policy imposing greater restrictions on broadcast of indecent language. In a 5-4 decision, the Court rejected the claim that the FCC had failed to adequately justify its change in policy and thereby violated the APA's prohibition on arbitrary and capricious agency action. Justice Scalia's majority opinion focused on defeating the suggestion that an agency necessarily faces a higher burden to explain a change in existing policy than to adopt a new policy when none previously had existed. ${ }^{19}$ But the opinion also denied that agency decisions implicating constitutional liberties trigger more stringent arbitrary and capricious review. Instead, the Court said, whether an agency action is "arbitrary and capricious" and whether it is unconstitutional are "separate questions." 20 Arguing that the canon of constitutional avoidance applied only to judicial review of statutory language, Justice Scalia stated that "the only context in which constitutionality bears upon judicial review of authorized agency action" is when a court determines the agency action is unconstitutional. ${ }^{21} \mathrm{He}$ dismissed the dissent's suggestion that the agency be required to reconsider its policy in light of constitutional concerns, terming such an approach "judicial arm-twisting or appellate review by the wagged finger." ${ }^{12}$

${ }^{18} 129$ S. Ct. 1800, 1812 (2009) ("If the Commission's action here was not arbitrary or capricious in the ordinary sense, it satisfies the Administrative Procedure Act's 'arbitrary [or] capricious' standard; its lawfulness under the Constitution is a separate question to be addressed in a constitutional challenge.").

${ }^{19}$ Id. at 1810 (stating there is "no basis in the Administrative Procedure Act or in our opinions for a requirement that all agency change be subjected to more searching review").

${ }^{20}$ Id. at 1812.

${ }^{21}$ Id.

${ }^{22}$ Id. at 1812 n.3. In his dissent, Justice Breyer emphasized that First Amendment censorship concerns are "as closely related to broadcasting regulation as is health to the environment" and that the FCC had justified its prior policy normally permitting single fleeting use of an expletive "upon the need to avoid 
Simply stated, my argument here is that Fox is wrong in positing a strict separation between constitutional and ordinary administrative law. The Court's protestations aside, constitutional concerns often affect judicial review of authorized executive action. In fact, constitutional law and ordinary administrative law are inextricably linked: Statutory and regulatory measures are created to address constitutional requirements; constitutional concerns, particularly those sounding in separation of powers, underlie core ordinary administrative law doctrines; and agencies are encouraged to take constitutional concerns seriously in their decisionmaking. The net result is that a fair amount of ordinary administrative law qualifies as constitutional common law. Its doctrines and requirements are constitutionally informed but rarely constitutionally mandated, with Congress and agencies enjoying broad power to alter specific administrative mechanisms notwithstanding their constitutional aspect.

Recognizing the interrelationship between constitutional law and ordinary administrative law is important both for the ongoing debate over the legitimacy of constitutional common law and for the proper appreciation of the role administrative agencies can play in our constitutional order. Underlying many attacks on constitutional common law is a vision of constitutional law as having a narrow and determinate scope, with a clear divide separating constitutional and nonconstitutional law. Yet, in the context of administrative law at least, this divide simply does not exist. Although some administrative law requirements are plainly constitutionally required and others clearly rooted only in statutory or regulatory enactments, a number of basic doctrines occupy a middle ground. The latter are simultaneously based in ordinary law and constitutional law, and these two dimensions are too overlapping and interactive to be isolated. Administrative law thus suggests that the vision of constitutional law as a distinct and determinate entity is a false one. Moreover, this overlapping and interactive relationship between the constitutional and ordinary dimensions of administrative law,

treading too close to the constitutional line." Id. at 1833 (Breyer, J., dissenting). Contending that the FCC's two-sentence explanation of the change in its view about the constitutionality of prohibiting fleeting use was inadequate, he argued that "the FCC's failure to address this aspect of the problem calls for a remand to the agency." Id. at 1835 (internal quotation marks omitted). 
combined with Congress's broad control over the latter, is what serves to transform ordinary administrative law into a species of constitutional common law.

Of course, that as a descriptive matter judges infuse constitutional values into their development of administrative law doctrines or readings of ordinary administrative requirements does not, standing alone, suffice to justify the practice. But this deeply embedded practice does indicate the degree of disruption that would result were constitutional common law extirpated from administrative law. Moreover, the normative basis needed to justify such a disruption is lacking. In particular, seeking to enforce constitutional norms through ordinary administrative law better accords with constitutional principles, and may be less intrusive on the policymaking prerogatives of the political branches, than efforts to segregate out the two. This is true of judicial development of administrative law doctrines that respond to constitutional concerns associated with administrative government, for instance the doctrinal requirement of at times quite searching scrutiny of the reasonableness of agency decisionmaking. Such doctrines are closely akin to other common moves in the judicial constitutional law repertoire, in particular constitutional avoidance canons. In addition, addressing these concerns through ordinary administrative law preserves a degree of flexibility that better accommodates changing regulatory needs and Congress's primacy in structuring government than do more immutable constitutional law prescriptions, and is also more likely to yield meaningful constraints.

But the benefits of addressing constitutional concerns through ordinary administrative law are especially evident with respect to the form of administrative constitutionalism condemned in Fox: judicial use of ordinary administrative law to encourage agencies to take constitutional concerns seriously in their own decisionmaking. Administrative agencies today are responsible for much of the federal government's decisionmaking. Excluding such primary decisionmakers from a judicially enforceable obligation to include significant constitutional concerns in their deliberations is at odds with the structural imperatives of our constitutional system. Agencies are not only well positioned to enforce constitutional norms effectively, but they are also better able than courts to determine how to incorporate constitutional concerns into a given regulatory scheme with the least disruption. In addition, it is far easier for agencies to 
respond to judicial decisions remanding administrative actions for failure to take account of constitutional concerns than for Congress to respond to judicial invalidation of measures on constitutional grounds or judicial narrowing of statutes through the application of constitutional canons.

To my mind, the better critique is not the extent to which constitutional common law surfaces in administrative contexts, but rather the lack of transparency that accompanies it. The causes of the Court's reluctance to acknowledge the constitutional dimension of ordinary administrative law are murky, but likely center on concerns with preserving the proper judicial role - both ensuring that courts do not intrude into the policymaking realm of the political branches and protecting the Court's supremacy in constitutional interpretation. Whatever the cause, the harmful effects of this reluctance are evident. Judicial failure to openly acknowledge the constitutional role played by ordinary administrative law has left our understandings of the constitutional demands imposed on the modern administrative state underdeveloped and untested by criticism. This failure has further meant that the capacity of administrative agencies to advance and protect constitutional norms remains largely unexploited. At the same time, judicial obfuscation has undermined the extent to which agencies are held accountable for the constitutional judgments they do make.

In what follows, Part I identifies a number of ways that constitutional concerns permeate ordinary administrative law and argues that the net result is best understood as constitutional common law. Part II then analyzes the implications of this characterization of ordinary administrative law for the debate over constitutional common law and seeks to justify the use of ordinary administrative law to ensure that administrative agencies take constitutional concerns seriously in their decisionmaking.

\section{CONSTITUTIONAL COMMON LAW IN ADMINISTRATIVE CONTEXTS}

Constitutional law regularly surfaces in administrative contexts, shaping how agencies make decisions, the substance of those decisions, and judicial review of agency decisionmaking. Yet that role is surprisingly unacknowledged and unspecified, particularly by 
courts. ${ }^{23}$ Similarly unremarked is the influence that ordinary administrative law has on defining the scope of constitutional rights. These two features - the tacit and indeterminate role played by constitutional concerns, as well as the reciprocal relationship between statutory or regulatory administrative mechanisms and constitutional requirements - mean that Congress has power over the substance of administrative law, including its constitutional components.

Combined with the evolving and emergent quality of many ordinary administrative law doctrines, the net result is a form of constitutional common law.

\section{A. Connections Between Constitutional Law and Ordinary Administrative Law}

Constitutional law's manifestations in administrative contexts can usefully be divided into three categories. First, ordinary administrative law provides mechanisms that are either constitutionally mandated or that avoid constitutional violations. Second, constitutional norms and concerns underlie and are evident in a number of administrative law doctrines. Third, both courts and the political branches sometimes use doctrinal mechanisms and substantive requirements to encourage agencies to take constitutional concerns seriously, with the result that constitutional concerns influence the shape of agency decisionmaking.

1. Ordinary Administrative Law as Constitutionally Mandated. The most obvious point of contact between ordinary administrative law and constitutional law is that ordinary administrative constraints on executive officials are sometimes constitutionally required. Perhaps the classic example is provisions for administrative hearings, which are often adopted to satisfy procedural due process's

${ }^{23}$ Scholars periodically notice the constitutional underpinnings of ordinary administrative law doctrines. See, e.g., Bressman, Beyond Accountability, supra note 17 , at 468 (noting "possibility that the concern for arbitrariness, a staple of administrative law, actually emanates from the constitutional structure"); Kevin M. Stack, The Constitutional Foundations of Chenery, 116 Yale L.J. 952, 958-59 (2007) (arguing Chenery principle is implementation of nondelegation doctrine); see also William D. Araiza, In Praise of a Skeletal APA: Norton v. Southern Utah Wilderness Alliance, Judicial Remedies for Agency Inaction, and the Questionable Value of Amending the APA, 56 Admin. L. Rev. 979, 1002 (2004) (noting "the maxim that administrative law is applied constitutional law"). 
requirements of notice and some opportunity to be heard. ${ }^{24}$ Another instance involves the First Amendment. The Court has repeatedly held that administrative licensing systems or other forms of prior restraint based upon the content of speech must contain objective standards to circumscribe official discretion in order to be constitutional, as well as procedural safeguards such as the right to speedy judicial review of any administrative license denial. ${ }^{25}$ Most recently, the Court's decisions on parade licensing have underscored the importance of officials' being required to explain their decisions, a typically administrative requirement. ${ }^{26}$

${ }^{24}$ See, e.g., Wilkinson v. Austin, 545 U.S. 209, 216-17, 225-30 (2005)

(detailing administrative system used for classifying prisoners for supermax, which included provisions for notice, hearing, and internal review, and concluding that this system, devised on the eve of trial, satisfied procedural due process requirements); see also Matthew C. Stephenson, The Price of Public Action: Constitutional Doctrine and the Judicial Manipulation of Legislative Enactment Costs, 118 Yale L.J. 2, 31-32 (2008) (arguing that in a number of instances government is required to use elaborate procedures if adopting a constitutionally doubtful decision).

${ }^{25}$ See City of Lakewood v. Plain Dealer Publ'g Co., 486 U.S. 750, 769-72 (1988) (invalidating ordinance giving mayor complete discretion in granting or denying permits to place news racks on public property); Freedman v. Maryland, 380 U.S. 51, 58-59 (1965) (requiring procedural safeguards for film licensing system to be constitutional, including prompt access to court to review license denial); Cox v. New Hampshire, 312 U.S. 569, 575-76 (1941) (upholding parade and march regulation as interpreted by state court to deny town arbitrary or unfettered discretion over issuance of permits); see also Forsyth County $v$. Nationalist Movement, 505 U.S. 123, 133 (1992) (holding county parade fee ordinance unconstitutional because it lacked objective standards for fee assessments, did not require explanations for fee decisions, and did not provide for review); Reuel E. Schiller, Free Speech and Expertise: Administrative Censorship and the Birth of the Modern First Amendment, $86 \mathrm{Va}$. L. Rev. 1, 2-3 (2000) (discussing historical intertwining of free speech claims and administrative law).

${ }^{26}$ See Forsyth County, 505 U.S. at 133 (noting ordinance in question does not require administrator to explain his decision and finding "such unbridled discretion" constitutionally prohibited); see also Thomas v. Chi. Park Dist., 534 U.S. 316, 324 (2002) (upholding parade licensing scheme that limited factors government officials could consider, required that reasons for any denials be clearly explained, and subjected decisions to review); Seattle Coal. to Stop Police Brutality v. City of Seattle, 550 F.3d 788, 798 (9th Cir. 2008) ("The Supreme Court has expressed particular concern about statutes that do not require the licensor to 'provide any explanation for his decision, and [where] that decision is unreviewable."' (alteration in original) (quoting Forsyth County, 505 U.S. at 133)). 
In other contexts, specific administrative mechanisms are not constitutionally mandated but suffice to avoid constitutional violations. A prime example here arises in regard to Bivens actions. ${ }^{27}$ On several occasions, the Court has identified the availability of administrative complaint systems to redress individual harms as a factor counting against implying a Bivens damages remedy. ${ }^{28}$ Yet another example is the separation of functions requirements of the APA and other provisions for independent agency review. ${ }^{29}$ Although the Court has rejected the claim that combining investigative and adjudicatory functions necessarily violates due process, it has also acknowledged the possibility that such a combination may undermine an individual's due process right to an unbiased decisionmaker. ${ }^{30}$ Such a possibility is forestalled, however, by the APA's separation of functions requirements. Indeed, due process concerns underlay Congress's decision to include these provisions as well as other procedural protections for formal agency adjudication in the APA. ${ }^{31}$ Like the procedural process and First

${ }^{27}$ Bivens v. Six Unknown Named Agents of Fed. Bureau of Narcotics, 403 U.S. 388, 396-97 (1971) (recognizing an implied private right of action for damages against federal officers alleged to have violated constitutional rights).

${ }^{28}$ See Wilkie v. Robbins, 551 U.S. 537, 551-53, 561-62 (2007) (emphasizing availability of existing mechanisms for administrative and subsequent judicial review and concluding that such availability, along with functional concerns, made Bivens action inappropriate); Corr. Servs. Corp. v. Malesko, 534 U.S. 61, 74 (2001) (noting respondents had full access to administrative remedy program in refusing to infer Bivens action against private prison corporation); Schweiker $v$. Chilicky, 487 U.S. 412, 424-25 (1988) (highlighting administrative review process available to social security disability claimants, including option of seeking judicial review once administrative remedies were exhausted, in refusing to imply a Bivens action); Bush v. Lucas, 462 U.S. 367, 385-86 (1983) (concluding that administrative system created by Congress "provides meaningful remedies for employees who may have been unfairly disciplined for making critical comments about their agencies" and refusing to create a Bivens action for alleged First Amendment violations).

${ }^{29}$ See 5 U.S.C. $\$ 554,556-557$ (2006).

${ }^{30}$ See Withrow v. Larkin, 421 U.S. 35, 46-55 (1975) (rejecting claim that combination of investigative and adjudicatory functions necessarily violates due process); see also In re Murchison, 349 U.S. 133, 139 (1955) (holding that procedure under which judge charged witnesses with contempt, and also tried and convicted them, violated due process).

${ }^{31}$ See William S. Jordan, III, Chevron and Hearing Rights: An Unintended Combination, 61 Admin. L. Rev. 249, 299-312 (2009) (describing importance 
Amendment licensing decisions discussed above, constitutional concerns are acknowledged to be in play in these contexts. But the Court has not held these administrative mechanisms to be constitutionally required, instead simply concluding they are adequate to avoid constitutional violations. The result is that governments enjoy greater discretion in shaping these administrative mechanisms as they determine best. ${ }^{32}$

Ordinary administrative law can serve an even greater avoidance role - not only guarding against recognized constitutional violations, but also allowing courts to avoid addressing some constitutional issues at all. Again, procedural due process provides a case in point. The Court periodically insists that procedural due process imposes no significant constraints on general policymaking. In doing so, however, it relies on precedents going back to the beginning of the twentieth century, before the advent of the modern administrative state, in which rulemaking is pervasive and agencies exercise broad discretion in devising requirements that can have a substantial impact on identified groups. ${ }^{33}$ The Court has not had to address the question

placed on ensuring neutral decisionmakers and procedural protections in development of APA formal adjudication requirements). See generally George B. Shepherd, Fierce Compromise: The Administrative Procedure Act Emerges from New Deal Politics, 90 Nw. U. L. Rev. 1557 (1996) (detailing history behind enactment of the APA).

${ }^{32}$ This is particularly true in contrast to the First Amendment licensing context, where the Court has imposed fairly specific procedural requirements. See Forsyth County v. Nationalist Movement, 505 U.S. 123, 133 (1992) ("The First Amendment prohibits the vesting of ... unbridled discretion in a government official."). The Court is often quite deferential to governmental choices in assessing procedural due process challenges. See, e.g., Walters $v$. Nat'l Ass'n of Radiation Survivors, 473 U.S. 305, 323-26 (1985) (emphasizing great weight due government's desire to preserve informality and nonadversarial character of veterans' benefits system).

${ }^{33}$ The Court's decisions rejecting such procedural due process claims also involved contexts in which substantial opportunity for notice and comment had been provided. See, e.g., United States v. Fla. E. Coast Ry. Co., 410 U.S. 224, 24346 (1973) (invoking Londoner v. City of Denver, 210 U.S. 373 (1908), and BiMetallic Inv. Co. v. State Bd. of Equalization, 239 U.S. 441 (1915), and holding procedural due process did not require additional rulemaking procedures where agency's ultimate notice "could not have been more explicit or detailed" and interested parties had sufficient time to object); see also Vt. Yankee Nuclear Power Corp. v. Natural Res. Def. Council, Inc., 435 U.S. 519, 542 n.16 (1978) (citing BiMetallic and Florida East Coast and stating "since this was clearly a rulemaking 
of whether procedural due process requires some minimal level of notice and opportunity to be heard with respect to regulatory rulemaking in its modern form because the APA already mandates such procedures. ${ }^{34}$ Similarly, Lisa Bressman has argued that the availability of ordinary administrative law doctrines that prohibit arbitrary agency decisionmaking has allowed the Court to avoid determining whether the Constitution requires agencies to issue standards to guide the exercise of their delegated powers. ${ }^{35}$

2. Ordinary Administrative Law as Constitutionally Inspired. The description of ordinary administrative law as allowing courts to avoid constitutional issues is only partially accurate. It fails to capture the ways that constitutional concerns have shaped the development of ordinary administrative law doctrines - sometimes overtly, often tacitly. The emergence of hard look review of agency decisionmaking exemplifies this phenomenon. The APA's prohibition on arbitrary and capricious agency action today provides the basis for at times quite searching judicial scrutiny. As the Court famously stated in Motor Vehicle Manufacturers Ass'n v. State Farm Mutual Automobile Insurance Co.: "The agency must examine the relevant data and articulate a satisfactory explanation for its action[,] including a 'rational connection between the facts found and the choice made."'36 Moreover, courts are instructed to set aside agency

proceeding in its purest form, we see nothing to support [the] view" that "additional procedural devices were required under the Constitution," in regard to a rulemaking in which the agency had provided detailed notice, including underlying staff reports, and had held an oral hearing).

${ }^{34}$ See 5 U.S.C. $\S 553$ (outlining APA rulemaking procedures).

${ }^{35}$ See Bressman, Beyond Accountability, supra note 17, at 518 ("[The Court] might ... refuse to ask agencies for the requisite standards under 'constitutional' administrative law ... because reviewing courts could ask agencies for such standards under 'ordinary' administrative law ... ."); Lisa Schultz Bressman, Disciplining Delegation After Whitman v. American Trucking Ass'ns, 87 Cornell L. Rev. 452, 459-66 (2002) ("Rules of judicial restraint support a shift from constitutional law to administrative law to require administrative standards.").

${ }^{36} 463$ U.S. 29, 43 (1983) (quoting Burlington Truck Lines, Inc. v. United States, 371 U.S. 156, 168 (1962)). The recent Fox decision "rejects the notion that all shifts in agency policy are subject to more rigorous judicial review," and appears more willing than State Farm to allow agencies "to change their policies due to changes in the political landscape." Kathryn A. Watts, Proposing a Place for Politics in Arbitrary and Capricious Review, 119 Yale L.J. 2, 22 (2009). But Fox did not call the general practice of hard look review into question. See $F C C v$. Fox 
action if they find an agency relied on factors which Congress has not intended it to consider, entirely failed to consider an important aspect of the problem, offered an explanation for its decision that runs counter to the evidence before [it], or is so implausible that it could not be ascribed to a difference in view or the product of agency expertise. $^{37}$

It is generally accepted, at least by scholars, that "arbitrary and capricious" review under State Farm is a far cry from the lenient scrutiny originally intended by the Congress that enacted the APA. When the APA was adopted, arbitrary and capricious was understood to entail the same minimal scrutiny as constitutional rationality review. Over the years, however, the courts came to read arbitrary and capricious in an increasingly rigorous fashion until it came to embody today's hard look review. ${ }^{38}$

Part of the explanation for this expansion of substantive judicial scrutiny of agency decisionmaking lies in constitutional concerns with broad delegations of power to agencies and the attendant risk of unaccountable and arbitrary exercises of administrative power. Intensified judicial scrutiny of administrative actions developed in response to the dramatic expansion in regulatory authority that accompanied enactment of major environmental, health and safety, and consumer protection statutes during the 1960s and 1970s. This period was also marked by increasing loss of faith in administrative

Television Stations, Inc., $129 \mathrm{~S} . \mathrm{Ct} .1800,1810-11$ (2009) (noting "the requirement that an agency provide reasoned explanation for its action would ordinarily demand that it display awareness that it is changing position" and insisting that rejection of heightened scrutiny accords with State Farm).

${ }^{37}$ State Farm, 463 U.S. at 43.

${ }^{38}$ See Alfred C. Aman, Jr., Administrative Law in a Global Era: Progress, Deregulatory Change, and the Rise of the Administrative Presidency, 73 Cornell $L$. Rev. 1101, 1110 n.28,1134-43 (1988) ("The 'arbitrary, capricious and an abuse of discretion' standard was applied much like the reasonableness standard for legislation ... . But ... the Court was willing, post-APA, to demand that an agency ... provide reasons that justify its policy."); Robert L. Rabin, Federal Regulation in Historical Perspective, 38 Stan. L. Rev. 1189, 1300-15 (1986) (describing "judicial activism" and "much closer scrutiny of agency decisions," which culminated in "what Judge Harold Leventhal aptly labeled 'the hard look"'). For an example of the type of deferential scrutiny originally thought to be the measure of arbitrary and capricious review, see Pac. Sts. Box \& Basket Co. v. White, 296 U.S. 176, 181-82 (1935) ("With the wisdom of such a regulation we have, of course, no concern. We may enquire only whether it is arbitrary or capricious."). 
expertise and fears of agency capture by regulated interests. ${ }^{39}$ The requirement that agencies supply substantial, contemporaneous, and reasoned explanations for their decisions exerts a powerful disciplining force on the agency's decisionmaking process. ${ }^{40} \mathrm{In}$ particular, hard look review prioritizes expertise and technocratic decisionmaking within the agency, in the process downplaying more raw political considerations. ${ }^{41}$ At the same time, requiring that

${ }^{39}$ See Thomas W. Merrill, Capture Theory and the Courts: 1967-1983, 72 Chi.-Kent L. Rev. 1039, 1039-44, 1059-67 (1997) [hereinafter Merrill, Capture Theory] ("Many federal judges became convinced that agencies were prone to capture and related defects and - more importantly - that they were in a position to do something about it."); Rabin, supra note 38, at 1295-315 (describing judicial turn to close supervision in response to suspicions about agency good faith and expertise combined with increasing scientific and technological complexity and high-stakes rulemaking); see also Gillian E. Metzger, The Story of Vermont Yankee: A Cautionary Tale of Judicial Review and Nuclear Waste, in Administrative Law Stories 125, 143-48 (Peter L. Strauss ed., 2006) [hereinafter Metzger, Vermont Yankee] (tracing D.C. Circuit's responses to concerns about agency accountability presented by expanded rulemaking).

${ }^{40}$ Some scholars say too disciplining. See, e.g., Jerry L. Mashaw \& David L. Harfst, The Struggle for Auto Safety 224-28 (1990) ("The result of judicial requirements for comprehensive rationality has been a general suppression of the use of rules."); R. Shep Melnick, Regulation and the Courts: The Case of the Clean Air Act 294-98 (1983) ("The practical effect of the courts' apparently evenhanded procedures is far from politically neutral because their substantive pronouncements severely limit the issues that intervenors can discuss."); Thomas O. McGarity, Some Thoughts on "Deossifying" the Rulemaking Process, 41 Duke L.J. 1385, 1387-96, 1400-03, 1419 (1992) (detailing adverse consequences of increasing burdens and rigidities of informal rulemaking and identifying judicially imposed analytic requirements as a major cause); Richard J. Pierce, Jr., Seven Ways to Deossify Agency Rulemaking, 47 Admin. L. Rev. 59, 60-62, 65-68 (1995) ("No agency can perform [a regulatory] mission in today's legal environment."). For more optimistic accounts of the benefits of hard look review, see William F. Pedersen, Jr., Formal Records and Informal Rulemaking, 85 Yale L.J. 38, 59-60 (1975) (arguing "the effect of such detailed factual review by the courts on the portion of the agency subject to it is entirely beneficial" and noting such review "gives those who care about well-documented and well-reasoned decisionmaking a lever with which to move those who do not"); Mark Seidenfeld, Cognitive Loafing, Social Conformity, and Judicial Review of Agency Rulemaking, 87 Cornell L. Rev. $486,490-91,522-26,543-47$ (2002) (drawing on psychology of decisionmaking to argue arbitrary and capricious review may improve the overall quality of rules).

${ }^{41}$ See Jody Freeman \& Adrian Vermeule, Massachusetts v. EPA: From Politics to Expertise, 2007 Sup. Ct. Rev. 54, 64-66, 87-88 (identifying hard look review and reasoned decisionmaking requirements as serving an expertise forcing 
agencies explain and justify their actions also arguably reinforces political controls by helping to ensure that Congress and the President are aware of what agencies are doing. ${ }^{42}$

In short, this basic requirement of reasoned explanation is central to alleviating core separation of powers concerns associated with the administrative state. ${ }^{43}$ In his recent Fox concurrence, Justice Kennedy noted this constitutional connection, describing the reasoned decisionmaking requirement as "stemming from the administrative agency's unique constitutional position" and the danger that "if agencies were permitted unbridled discretion, their actions might violate important constitutional principles of separation of powers and checks and balances." ${ }^{44}$ The Court implicitly made a similar link

function and reflecting a "vision of administrative law in which independence and expertise are seen as opposed to, rather than defined by, political accountability"); Watts, supra note 36 , at 19-20, 23-29 (characterizing current arbitrary and capricious review as "representing the triumph of expertise to the exclusion of politics" in administrative decisionmaking and detailing extent to which agencies now generally fail to disclose political factors influencing decisionmaking).

${ }^{42}$ See Lisa Schultz Bressman, Procedures as Politics in Administrative Law, 107 Colum. L. Rev. 1749, 1780-83 (2007) [hereinafter Bressman, Procedures] ("The reasoned decisionmaking requirement provides Congress ... with access to information about agency action before such action is final."); Mathew D. McCubbins, Roger G. Noll \& Barry R. Weingast, Structure and Process, Politics and Policy: Administrative Arrangements and the Political Control of Agencies, 75 Va. L. Rev. 431, 441-43 (1989) ("Administrative procedures ... force the agency to move slowly and publicly, giving politicians (informed by their constituents) time to act before the status quo is changed."); Stack, supra note 23, at 958-59 (describing requirement that agency action be assessed solely on the agency's stated reasons as "providing assurance that accountable agency decision-makers, not merely courts and agency lawyers, have embraced the grounds for the agency's actions").

${ }^{43}$ See Sidney A. Shapiro \& Richard E. Levy, Heightened Scrutiny of the Fourth Branch: Separation of Powers and the Requirement of Adequate Reasons for Agency Decisions, 1987 Duke L.J. 387, 425-28 (detailing history of the reasongiving requirement and its basis in separation of powers); see also Jerry $\mathrm{L}$. Mashaw, Reasoned Administration: The European Union, the United States, and the Project of Democratic Governance, 76 Geo. Wash. L. Rev. 99, 111 (2007) (noting constitutional basis of reasoned decisionmaking requirement); Richard W. Murphy, The Limits of Legislative Control Over the "Hard-Look," 56 Admin. L. Rev. 1125, 1132-34 (2004) (same); Stack, supra note 23, at 992-1000 (describing separation of powers justifications for nondelegation doctrine).

${ }^{44}$ FCC v. Fox Television Stations, Inc., 129 S. Ct. 1800, 1823 (2009)

(Kennedy, J., concurring in part and concurring in the judgment); see also Bowen $v$. 
in State Farm, emphasizing the difference between statutes and administrative action and arguing that the latter did not merit the same "presumption of constitutionality" and minimal rationality review due the former. ${ }^{45}$ Similarly, as Kevin Stack demonstrated in his recent article on the landmark SEC v. Chenery decision, the demand that agencies offer a contemporaneous statement of the grounds for their actions derives from modern constitutional concerns about delegation of authority to administrative agencies. ${ }^{46}$ The Court made this connection express in opinions issued in the early decades of the twentieth century, as the modern administrative state was beginning to emerge, stating, "in creating such an administrative agency the legislature, to prevent its being a pure delegation of legislative power, must enjoin upon it a certain course of procedure and certain rules of decision in the performance of its function."17?

Today, however, the Court is less willing to acknowledge the constitutional basis of the reasoned decisionmaking demand; Kennedy's statement in Fox is quite unusual. Despite highlighting the

Am. Hosp. Ass'n, 476 U.S. 610, 627 (1986) ("Our recognition of Congress' need to vest administrative agencies with ample power to assist in the difficult task of governing a vast and complex industrial Nation carries with it the correlative responsibility of the agency to explain the rationale and factual basis for its decision."). Jerry Mashaw has argued that the core administrative law notion that "discretion is always conferred on administrators on the implicit assumption that it will be reasonably exercised" is evident in an 1815 opinion by Chief Justice Marshall in Otis v. Watkins, 13 U.S. (9 Cranch) 339, 358 (1815) (Marshall, C.J., separate opinion), although the Court itself rejected the requirement that a government official must use "reasonable care in ascertaining the facts on which to form an opinion," id. at 355-56 (majority opinion). Jerry L. Mashaw, Reluctant Nationalists: Federal Administration and Administrative Law in the Republican Era, 1801-1829, 116 Yale L.J. 1636, 1677-78 (2007).

${ }^{45}$ Motor Vehicle Mfrs. Ass'n v. State Farm Mut. Auto. Ins. Co., 463 U.S. 29, 43 $n .9$ (1983).

${ }^{46}$ Stack, supra note 23, at 982-89; cf. Ann Woolhandler, Delegation and Due Process: The Historical Connection, 2008 Sup. Ct. Rev. 223, 225-26 (analyzing effect of legislative delegation on procedural due process and arguing that the Court initially imposed process requirements on delegees to ensure their determinations had factual support, but "later supplemented, or in some cases replaced, the requirement of process with a requirement - enforced by judicial review - that the delegee's action not be substantively arbitrary").

${ }^{47}$ Wichita R.R. \& Light v. Pub. Utils. Comm'n, 260 U.S. 48, 58-59 (1922); see also Stack, supra note 23 , at $983-89$ (discussing Wichita Railroad and similar contemporaneous decisions). 
distinctive position of agencies, State Farm ultimately rooted hard look review simply in the APA's prohibition on arbitrary and capricious agency action, without addressing whether such intense scrutiny was originally intended. ${ }^{48}$ Even more striking is the 2001 decision in Whitman v. American Trucking Ass'ns. The Court there insisted that the constitutionality of a delegation turns solely on whether Congress supplied an intelligible principle to guide the agency and not on how the agency exercises its delegated power. ${ }^{49}$ Although the Court also indicated that what counts as a constitutionally sufficient intelligible principle may vary with the scope and nature of delegated responsibilities, unlike earlier precedent it treated the presence of alternative checks, such as agency-promulgated limits or even judicial oversight, as irrelevant ${ }^{50}$ The constitutional forces that produced contemporary

48 State Farm, 463 U.S. at 41-43; see also Citizens to Preserve Overton Park, Inc. v. Volpe, 401 U.S. 402, 415 (1971) (similarly invoking only the APA, though with general references to the appropriate roles of courts and agencies). The Court's refusal to address whether extensive substantive scrutiny accords with the intentions of Congress in adopting the APA stands in particular contrast to its insistence that courts not impose procedural controls beyond those in the APA. See Metzger, Vermont Yankee, supra note 39, at 160-62 (discussing distinction between procedure and substance in judicial review in aftermath of Vermont Yankee). Compare Vt. Yankee Nuclear Power Corp. v. Natural Res. Def. Council, Inc., 435 U.S. 519, 523-24, 543-44 (1978) (refusing to require additional procedures for informal rulemaking beyond those specified in the APA), with id. at 549 (remanding for determination of whether decision was sustainable on the administrative record).

49531 U.S. 457, 472 (2001). The specific issue in Whitman was whether an agency's failure to adopt determinative guidelines to limit its discretion created an unconstitutional delegation, but the Court's insistence that an agency's actions in exercising its delegated authority are irrelevant to assessing the delegation's constitutionality would presumably extend to denying the relevance of whether the agency engaged in reasoned decisionmaking. Whitman does not, however, exclude the possibility that the reasoned decisionmaking requirement is rooted in the Due Process Clause.

${ }^{50}$ Id. at 475. The Court's refusal in Whitman to link judicial review to the constitutionality of delegations was at odds with its opinion in INS v. Chadha, 462 U.S. 919 (1983), which stated that "the bicameral process is not necessary as a check on the Executive's administration of the laws because his administrative activity cannot reach beyond the limits of the statute that created it" and emphasized that "the courts, when a case or controversy arises, can always 'ascertain whether the will of Congress has been obeyed' and can enforce adherence to statutory standards." Id. at 953 n.16 (quoting Yakus v. United States, 321 U.S. 
arbitrary and capricious review have thus faded from immediate view. Yet they nonetheless represent a fundamental basis on which this basic administrative law doctrine rests.

The role that constitutional concerns play in inspiring ordinary administrative law is even more evident in Chevron v. Natural Resources Defense Council, Inc., which famously established the rule that courts should defer to reasonable agency interpretations of ambiguous statutes that the agencies are charged with implementing. ${ }^{51}$ Chevron creates a mechanism for checking agencies somewhat different from hard look review, in that it emphasizes political controls in addition to (some scholars argue more than) agency reasoning and expertise. ${ }^{52}$ The Court's explanation in

414, 425 (1944), and citing Youngstown Sheet \& Tube Co. v. Sawyer, 343 U.S. 579 , 585 (1952)); see also Amalgamated Meat Cutters \& Butcher Workmen of N. Am. v. Connally, 337 F. Supp. 737, 758 (D.D.C. 1971) ("Another feature that blunts the 'blank check' rhetoric is the requirement that any action taken by the Executive under the law ... be in accordance with further standards as developed by the Executive."); Cynthia R. Farina, Statutory Interpretation and the Balance of Power in the Administrative State, 89 Colum. L. Rev. 452, 485-88 (1989) (detailing shift in delegation doctrine between a focus on "power divided to power kept in check").

51467 U.S. 837, 843 (1984). More specifically, Chevron famously established that courts are instructed to undertake a two-step inquiry in assessing agency statutory interpretations. At the first step, the court asks whether the statute's plain terms "directly address[] the precise question at issue." Id. If the statute is ambiguous on the point, the court defers at step two to the agency's interpretation so long as the construction is "a reasonable policy choice for the agency to make." Id. at 845 . Subsequent decisions have made clear that a court must initially establish that "Congress delegated authority to the agency generally to make rules carrying the force of law, and that the agency interpretation claiming deference was promulgated in the exercise of that authority" for Chevron deference to apply - a requirement occasionally referred to as Chevron's step zero. United States v. Mead Corp., 533 U.S. 218, 226-27 (2001).

\$2 See Bressman, Procedures, supra note 42, at 1763-65 ("Chevron, more than any other case, is responsible for anchoring the presidential control model ... recognizing that politics is a permissible basis for agency policymaking."); Watts, supra note 36, at 35-38 ("Chevron underscored the relevance of political influences ... to agencies' interpretive processes."). But see Peter L. Strauss, Overseer, or "The Decider"? The President in Administrative Law, 75 Geo. Wash. L. Rev. 696, 752 (2006) ("While Chevron sensibly accepts the President's political role as mediating the difficulties of focused bureaucratic expertise, it does not purport to displace reliance on the latter... . Not a word in Chevron suggests tolerance for the proposition that [a] decision could be made by anyone but the administrator of the EPA ...."). 
Chevron for this deference rule was cursory, but it suggested that one basis was congressional intent, arguing that in delegating implementation to an agency Congress was also implicitly delegating gap-filling interpretive authority. ${ }^{53}$ Yet such an across-the-board implication of congressional intent is, of course, purely fictional. ${ }^{54}$ The real question is why read statutory delegations as including implicit delegation of interpretive authority, rather than insist that courts exercise independent judgment on questions of statutory meaning absent express instructions from Congress to the contrary. The Court appears to have been influenced both by separation of powers and institutional competency concerns about the appropriate judicial role, combined with recognition of the impossibility of separating questions of statutory meaning from questions of policy. ${ }^{55}$ Later in the opinion the Court acknowledged this constitutional basis for its approach, emphasizing the impropriety of judges making policy decisions as well as the need to leave such determinations to

53467 U.S. at 844.

${ }^{54}$ See David J. Barron \& Elena Kagan, Chevron's Nondelegation Doctrine, 2001 Sup. Ct. Rev. 201, 212-20 ("Because Congress so rarely makes its intentions about deference clear, Chevron doctrine at most can rely on a fictionalized statement of legislative desire, which in the end must rest on the Court's view of how best to allocate interpretive authority."). Indeed, the Chevron Court appeared to acknowledge as much. See 467 U.S. at 865 (describing several possible accounts of why Congress adopted the statutory language it did, and stating "for judicial purposes, it matters not which of these things occurred").

${ }^{55}$ See, e.g., Farina, supra note 50, at 456 ("Chevron invoked the principles of separation of powers and legitimacy."); Jerry L. Mashaw, Norms, Practices, and the Paradox of Deference: A Preliminary Inquiry into Agency Statutory Interpretation, 57 Admin. L. Rev. 501, 505 (2005) [hereinafter Mashaw, Norms, Practices] ("Chevron relies on constitutional structure, Congress's legitimate authority to delegate lawmaking power ... and [agencies'] political accountability ... ."). Although most agree that constitutional concerns were one basis for Chevron, the extent to which Chevron's deference rule can be constitutionally justified has sparked some controversy. Compare Thomas W. Merrill \& Kristin E. Hickman, Chevron's Domain, 89 Geo. L.J. 833, 864-67, 870-73 (2001) (expressing doubt about constitutional basis of Chevron deference and rooting it instead in presumed congressional intent), with Richard J. Pierce, Jr., Reconciling Chevron and Stare Decisis, 85 Geo. L.J. 2225, 2227 (1997) (defending Chevron as constitutionally based), and Cass R. Sunstein, Law and Administration after Chevron, 90 Colum. L. Rev. 2071, 2086-91 (1990) (doubting separation of powers or congressional intent can justify Chevron and arguing instead that institutional competency concerns provide a plausible justification). 
officials politically accountable through the President: "The responsibilities for assessing the wisdom of ... policy choices and resolving the struggle between competing views of the public interest are not judicial ones: 'Our Constitution vests such responsibilities in the political branches."'56

Constitutional values also surface expressly when the Court invokes constitutional canons of interpretation in reading administrative statutes. ${ }^{57}$ For example, the Court has applied a "strong presumption that Congress intends judicial review of administrative action," a presumption rooted in both due process and separation of powers concerns. ${ }^{58} \mathrm{Just}$ last term, in Wyeth v. Levine, the Court relied in part on the federalism-inspired presumption against preemption in refusing to defer to the Food and Drug Administration's (FDA's) view that a state law failure to warn suit was preempted by the FDA's approval of the drug label at issue. ${ }^{59}$

${ }^{56}$ Chevron, 467 U.S. at 866 (quoting Tenn. Valley Auth. v. Hill, 437 U.S. 153, 195 (1978)); see also id. at 865 ("An agency to which Congress has delegated policymaking responsibilities may, within the limits of that delegation, properly rely upon the incumbent administration's views of wise policy ... . While agencies are not directly accountable to the people, the Chief Executive is ....").

${ }^{57} \mathrm{On}$ the role of the canons and constitutional values in interpreting regulatory statutes, see Cass R. Sunstein, Interpreting Statutes in the Regulatory State, 103 Harv. L. Rev. 405, 459, 469-74 (1989) [hereinafter Sunstein, Interpreting Statutes] ("Interpretive principles are often a product of constitutional norms."); see also William N. Eskridge, Jr., Public Values in Statutory Interpretation, $137 \mathrm{U}$. Pa. L. Rev. 1007, 1019-36 (1989) (discussing role of constitutional values in statutory interpretation generally, not limited to administrative contexts); Jonathan R. Siegel, Textualism and Contextualism in Administrative Law, 78 B.U. L. Rev. 1023, 1024, 1032-79 (1998) (arguing background normative principles are central to interpretation of administrative law statutes, though not linking these principles to specifically constitutional concerns).

${ }^{58}$ Bowen v. Mich. Acad. of Family Physicians, 476 U.S. 667, 670 (1986); see also Abbott Labs. v. Gardner, 387 U.S. 136, 140 (1967) (discussing strong presumption of judicial reviewability).

59129 S. Ct. 1187, 1194-95, 1198, 1200-02 (2009). In like fashion, the constitutional avoidance canon in particular is sometimes identified as a basis for denying the deference usually accorded reasonable agency statutory interpretations of ambiguous statutes under Chevron. See Rust v. Sullivan, 500 U.S. 173, 190-91 (1991) (acknowledging the Court's practice of, if possible, avoiding statutory interpretations that raise grave constitutional doubts, but concluding agency regulations at issue did not raise such doubts and thus canon did not prevent deference to Secretary's reasonable interpretation). 
Indeed, the Court has identified federalism concerns as supporting narrower interpretations of the scope of an agency's delegated authority or more aggressive statutory readings under step one of Chevron even when the constitutional canons are not in play. ${ }^{60}$ Several scholars have argued that nondelegation and other constitutional concerns underlie other notably narrow interpretations of administrative statutes, though the Court has often been less open about the constitutional basis of these decisions. ${ }^{61}$

3. Encouraging Administrative Constitutionalism. - The third connection between ordinary administrative law and constitutional law is significantly different. Rather than involving judicial assessment of constitutional requirements or judicial development of administrative law doctrines to respond to constitutional concerns, the approach here centers on encouraging agencies to take constitutional values and concerns into account in their decisionmaking. The goal of such administrative constitutionalism is not simply avoiding judicial invalidation of unconstitutional agency actions, but fostering a more affirmative and independent agency role in implementing constitutional requirements. This version of the

${ }^{60}$ See Gonzales v. Oregon, 546 U.S. 243, $269-75$ (2006) (emphasizing federalism concerns raised by Attorney General's interpretation of Controlled Substances Act but concluding it was not necessary to employ a clear statement rule or presumption against preemption to find the interpretation invalid); Gillian E. Metzger, Administrative Law as the New Federalism, 57 Duke L.J. 2023, 2032-36, 2063-69 (2008) [hereinafter Metzger, New Federalism] (providing examples where the Court used "fairly exacting scrutiny ... [and] its doing so appears driven in large part by federalism concerns").

${ }^{61}$ See, e.g., FDA v. Brown \& Williamson Tobacco Corp., 529 U.S. 120, 160 (2000) (refusing to read the Food, Drug, and Cosmetic Act as authorizing FDA regulation of tobacco, noting in part the substantial expansion in agency power that would result and stating Congress would not delegate "in so cryptic a fashion"); see also John F. Manning, The Nondelegation Doctrine as a Canon of Avoidance, 2000 Sup. Ct. Rev. 223, 227 [hereinafter Manning, Nondelegation] (characterizing Brown \& Williamson as animated by nondelegation concerns); Hiroshi Motomura, Immigration Law After a Century of Plenary Power: Phantom Constitutional Norms and Constitutional Interpretation, 100 Yale L.J. 545, 564-75, 580-600 (1990) (arguing that "phantom constitutional norms" - norms rooted in due process, equal protection, and the First Amendment, but fundamentally at odds with plenary power doctrine - underlie many immigration decisions); Cass R. Sunstein, Nondelegation Canons, 67 U. Chi. L. Rev. 315, 316 (2000) [hereinafter Sunstein, Nondelegation] (identifying a number of canons of statutory interpretation as motivated by nondelegation concerns). 
constitutional law-administrative law interplay is the one curtly dismissed in Fox, and on other occasions as well the Court has displayed ambivalence about encouraging such administrative constitutionalism. Nonetheless, this linkage between constitutional law and administrative decisionmaking surfaces with some regularity in judicial decisions, and it is often fostered by political branch enactments.

A recent illustration came in Wyeth, issued just a month before Fox. In the course of holding that courts ultimately have the power to decide when preemption exists, absent a delegation to agencies of power to preempt, the Court emphasized that it often gives "some weight" to an agency determination that state law would pose obstacles to a federal regulatory scheme. ${ }^{62}$ According to the Court, the weight actually given to "the agency's explanation of state law's impact on the federal scheme depends on its thoroughness, consistency, and persuasiveness." ${ }^{63}$ The Court then refused to defer to the FDA's opinion that its approval of a prescription drug label preempted state law failure to warn claims, noting the FDA had "reversed [its] own longstanding position without providing a reasoned explanation" and done so through a process that failed to offer "states or other interested parties notice or opportunity for comment." ${ }^{164}$ Wyeth's net effect is to give agencies a clear incentive to take federalism concerns raised by preemption seriously, solicit comments from affected governments, and carefully justify any conclusion that state law would be an impediment to a federal regulatory scheme.

Another recent decision displaying this type of connection between constitutional law and administrative decisionmaking is Boumediene v. Bush. ${ }^{65}$ In a 5-4 decision, the Court there held that the Military Commissions Act's restrictions on the ability of Guantanamo Bay detainees to challenge their detention through habeas corpus constituted a violation of the Suspension Clause. ${ }^{66}$ In so holding, Justice Kennedy's majority opinion underscored procedural

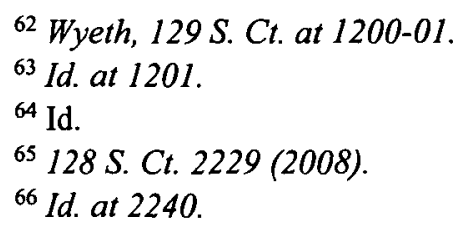


deficiencies with the government's internal administrative proceedings, the combatant status review tribunals (CSRTs), and repeatedly suggested that use of more robust internal procedural protections could lead to a different result. According to the Court, "the adequacy of the process through which [a detainee's] status determination was made" is a relevant factor "in determining the reach of the Suspension Clause." ${ }^{167}$ In addition, the Court emphasized that, in determining whether alternative procedures provide an adequate substitute for habeas, "what matters is the sum total of procedural protections afforded to the detainee at all stages, direct and collateral." ${ }^{68}$ Again, the effect is to give the government an incentive to craft internal administrative procedures that address the constitutional weakness the majority identified in the current system, specifically the detainees' limited ability to challenge the factual basis on which they are being held as enemy combatants, in order to limit the scope of subsequent judicial review. ${ }^{69}$

Decisions applying the constitutional avoidance canon to agency-administered statutes create similar incentives for agencies to take constitutional concerns seriously. ${ }^{70}$ Concern that a reviewing court may invoke the canon in lieu of Chevron deference may lead an agency to forgo broad assertions of authority or interpretations of ambiguous statutes that tread close to the constitutional pale. True, the agency thereby cedes some power it might prefer to preserve, but it forestalls an independent judicial determination of statutory meaning that could more significantly impinge on its authority. ${ }^{71}$ The

\section{${ }^{67}$ Id. at 2259.}

${ }^{68}$ Id. at 2269; see also id. at 2268 ("The necessary scope of habeas review in part depends upon the rigor of any earlier proceedings.").

69 The Obama administration initially appeared headed in this direction. See David Johnston, In Senate, Debate on Detainee Legal Rights, N.Y. Times, Jul. 8, 2009, at A18 ("Obama administration lawyers said ... that detainees prosecuted by military commissions should have some of the same constitutional rights as American citizens tried in civilian criminal courts.").

${ }^{70}$ See Trevor W. Morrison, Constitutional Avoidance in the Executive Branch, 106 Colum. L. Rev. 1189, 1197 (2006) (discussing agency incentives to apply the constitutional avoidance canon in the face of likely judicial review).

${ }^{71}$ In Rapanos v. United States, Chief Justice Roberts noted this point in castigating the Army Corps of Engineers and the EPA for failing to respond to a prior Supreme Court decision that had invoked constitutional concerns as grounds for refusing to defer to an agency interpretation of the Clean Water Act's (CWA's) 
immigration context provides a contemporary example of this dynamic. In Zadvydas v. Davis, the Court invalidated the government's interpretation of a federal immigration statute as authorizing indefinite detention of aliens ordered removable. The Court invoked the canon of constitutional avoidance as support for reading the statutes as authorizing only the detention of such aliens for a period reasonably necessary to secure their removal. ${ }^{72}$ In response, the government promulgated a new interpretation of the governing statute, one that preserved its authority to indefinitely detain some aliens but significantly narrowed the categories of aliens over which it could exercise such authority. The government argued in subsequent court challenges that its new regulation avoided the constitutional problems with its prior approach and therefore qualified for Chevron deference. ${ }^{73}$

Decisions like Wyeth, Boumediene, and Zadvydas signal the important role that administrative agencies play in ensuring that constitutional requirements are met. Initial responsibility for

scope. See 547 U.S. 715, 758 (2006) (Roberts, C.J., concurring) (arguing that given the "generous leeway [afforded agencies] in interpreting the statutes they are entrusted to administer," and the "broad, somewhat ambiguous, but nonetheless clearly limiting terms" of the CWA, "the Corps and the EPA would have enjoyed plenty of room to operate in developing some notion of an outer bound to the reach of their authority").

72533 U.S. 678, 682 (2001) (construing statute to contain reasonable time limitation to avoid raising "serious constitutional concerns"); see also Clark $v$. Martinez, 543 U.S. 371, 379 (2005) (holding the statutory interpretation of Zadvydas applies to aliens ordered removed who are inadmissible under the governing statute).

${ }^{73}$ See 8 C.F.R. $\S 241.14$ (a) (2009) (allowing detention of "particular removable aliens" on the basis of "special circumstances" but exempting "aliens who are not subject to the special review provisions under $\$ 241.13 "$ ); see also Continued Detention of Aliens Subject to Final Orders of Removal, $66 \mathrm{Fed}$. Reg. 56,967, 56,967 (Nov. 14, 2001); Brief For Appellants at 15-26, HernandezCarrera v. Carlson, 547 F.3d 1237 (10th Cir. 2008) (No. 08-3097). A circuit split currently exists on the question of whether the government's new regulation qualifies for Chevron deference. Compare Carlson, 547 F.3d at 1245-56, cert. denied, 175 L. Ed. $2 d 620$ (2009) (holding the new interpretation does not raise serious constitutional doubts and that Chevron deference is appropriate), with Tran v. Mukasey, 515 F.3d 478, 484 (5th Cir. 2008) (holding deference inappropriate). See also Kenneth A. Bamberger, Normative Canons in the Review of Administrative Policymaking, 118 Yale L.J. 64, 76-84 (2008) (describing case law on relationship between the constitutional canons and Chevron deference). 
addressing constitutional questions frequently falls to agencies. Moreover, although their decisions are subject to judicial scrutiny, agencies nonetheless are able to exert substantial influence in setting administrative policies or procedures that can have substantial constitutional import. Recognition of their ability to limit subsequent judicial interventions on constitutional grounds can be a powerful mechanism for encouraging agencies to take constitutional concerns seriously.

Interestingly, however, the Court rarely discusses this incentivizing effect. Wyeth and Boumediene are as express as it gets, and even in those cases the Court spoke somewhat indirectly, emphasizing that better agency decisionmaking and procedures might result in greater deference or avoidance of judicially imposed remedies rather than directly urging agencies to take constitutional concerns more seriously. Similarly, the Court rarely overtly acknowledges the incentives created by its constitutional canon decisions or its decisions holding that administrative protections can satisfy constitutional individual rights requirements. Indeed, in some contexts - the Fourth Amendment in particular - the Court has been notably reluctant to tie satisfaction of constitutional requirements to use of administrative measures in a way that would incentivize adoption of the latter. ${ }^{74}$ This is true even though the Court has implicitly linked these two and acknowledged the potential constitutional benefits of administrative measures that limit police officer discretion. ${ }^{75}$ Administrative constitutionalism is further

${ }^{74}$ See Whren v. United States, 517 U.S. 806, 815 (1996) (rejecting Fourth Amendment claim even though police officer's stop of automobile did not conform to governing police regulations); David A. Sklansky, Quasi-Affirmative Rights in Constitutional Criminal Procedure, 88 Va. L. Rev. 1229, 1275-76 \& nn.161-163 (2002) ("Outside [certain] narrow doctrinal categories, the Supreme Court has made clear that 'reasonableness' under the Fourth Amendment does not depend on either the promulgation or the observance of internal regulations by the police.").

${ }^{75}$ For implicit linkages, see, e.g., Mich. Dep't of State Police v. Sitz, 496 U.S. 444,454 (1990) (noting random stops involve the type of unconstrained discretion the Court has ruled must be circumscribed); New York v. Burger, 482 U.S. 691, 702-03 (1987) (upholding warrantless administrative inspections of closely regulated industries only if, among other factors, the discretion of inspecting officers is limited); see also Wayne R. LaFave, Controlling Discretion by Administrative Regulations: The Use, Misuse, and Nonuse of Police Rules and Policies in Fourth Amendment Adjudication, 89 Mich. L. Rev. 442, 445 (1990) ("The Court has sometimes expressly recognized that limits upon [police] 
discouraged by doctrines excusing constitutional challenges from the usual exhaustion requirements, as well as by the standard rule that the "adjudication of the constitutionality of congressional enactments has generally been thought beyond the jurisdiction of administrative agencies." ${ }^{176}$

Of greater relevance here, to the extent the Court has sought to encourage agencies to consider constitutional concerns, it has generally done so outside of ordinary administrative law doctrines and direct administrative review. Although Wyeth involved the question of how much deference to accord to an agency's interpretation of a statute as preemptive, it involved claims of preemption raised in a state tort suit and was not a direct challenge to administrative action. ${ }^{77}$ Boumediene was a constitutional challenge,

discretion are essential to the protection of Fourth Amendment values."); Sklansky, supra note 74, at 1275-76 \& nn.161-163 (listing examples). Academic commentators have long advocated reading the Fourth Amendment to require administrative rulemaking, and the Court supported the idea in dicta in United States v. Caceres, 440 U.S. 741, 755 (1979) ("Regulations governing the conduct of criminal investigations are generally considered desirable ...."). See generally, Anthony G. Amsterdam, Perspectives on the Fourth Amendment, 58 Minn. L. Rev. $349,415-28$ (1974) (arguing in favor of "legal directives that confine police discretion within reasonable bounds"); LaFave, supra, at 447-51 (discussing "system of rulemaking by law enforcement agencies" as way of cabining police discretion).

${ }^{76}$ Thunder Basin Coal Co. v. Reich, 510 U.S. 200, 215 (1994) (alteration in original) (internal quotation marks omitted). The Court's statements in this context have been somewhat ambivalent, as it has also emphasized that exhaustion "is not mandatory," id., and at times has urged the advantages of "providing the agency the opportunity to reconsider its policies, interpretations, and regulations in light of ... challenges," including constitutional claims, Shalala v. Ill. Council on Long Term Care, Inc., 529 U.S. 1, 24 (2000).

${ }^{77}$ See, e.g., Geier v. Am. Honda Motor Co., 529 U.S. 861, 883-86 (2000) (stating, in context of state tort suit, that Department of Transportation's position that a federal regulatory standard preempted state tort action at issue should be accorded "some weight," but holding deference unnecessary to conclude that preemption was appropriate); Medtronic, Inc. v. Lohr, 518 U.S. 470, 495-96 (1996) (stating, in context of state tort suit, that Court's determination that a statute did not preempt state tort claims was "substantially informed" by federal regulations and that the implementing agency's views of the statute should be given "substantial weight"); see also Watters v. Wachovia Bank, N.A., 550 U.S. 1, 20-21 \& n.13 (2007) (holding, in context of preemption declaratory judgment action, that federal statute clearly preempted state action at issue and thus the Court had no need to reach question of deference due federal agency's preemption determination). 
alleging that executive action had violated the Habeas Clause, rather than an administrative law challenge. Yet another example is the Court's indication that application of the constitutional canons trumps ordinary administrative law deference doctrines. ${ }^{78} \mathrm{I}$ have argued elsewhere that in recent decisions the Court has appeared to use administrative law as a mechanism for vindicating constitutional federalism concerns, ${ }^{79}$ but these moves are largely implicit and rarely acknowledged by the Court. ${ }^{80}$ Thus, as the Fox majority insisted, the

${ }^{78}$ See, e.g., Nw. Austin Mun. Util. Dist. No. One v. Holder, 129 S. Ct. 2504, 2513-17 (2009) (applying canon of constitutional avoidance and rejecting implementing agency's interpretation of Voting Rights Act without invoking deference); see also Bamberger, supra note 73, at 77-78 (describing the Court's position on relationship between the canon of constitutional avoidance and Chevron deference).

${ }^{79}$ In several instances - including Watters, 550 U.S. at 20-21, Massachusetts v. EPA, 549 U.S. 497, 528 (2007), and Gonzales v. Oregon, 546 U.S. 243, 258 (2006) - the Court used aggressive Chevron step zero or step one inquiries to avoid troubling federalism issues raised by federal agency preemption of state law. The Court has also been more willing to defer to agency action when the record indicates that an agency has been sensitive to the federalism implications of its actions. In a prior article, I described these moves by the Court as involving use of both ordinary and extraordinary administrative law to address federalism concerns, with extraordinary administrative law consisting of instances in which federalism concerns led the Court to differ in its application of ordinary or standard administrative law doctrines. See Metzger, New Federalism, supra note 60, at 2062, 2064-65. To avoid confusion, it is worth noting that here I am using the term "ordinary administrative law" somewhat differently, as meaning administrative law requirements and doctrines generally thought to be nonconstitutional, see supra text accompanying notes 15-17, and thus as encompassing both ordinary and extraordinary administrative law as I previously used these terms.

${ }^{80}$ See Metzger, New Federalism, supra note 60, at 2054-55, 2059-60

("Whether or not the Court perceives administrative law as serving a federalism function, it is at least approaching these cases in a manner that allows administrative law to play such a role."). The Court has been more overt about this connection in the past, much as it was previously more open about the constitutional bases of reasoned decisionmaking. See, e.g., Florida v. United States, 282 U.S. 194, 211-12 (1931) ("Whenever the federal power is exerted within what would otherwise be the domain of state power, the justification of the exercise of the federal power must clearly appear... . [If] the Commission undertakes to prescribe a statewide level of intrastate rates in order to avoid an undue burden, from a revenue standpoint, upon the interstate carrier, there should be appropriate findings upon evidence ... ." (citations omitted)). Notably, one recent occasion in which the Court did acknowledge that federalism concerns affected its analysis - the discussion of state standing in Massachusetts, 549 U.S. at 518-21 - 
Court does not appear to have expressly employed ordinary administrative doctrines, in particular arbitrary and capricious review, to force agencies to consider the significant constitutional implications of their actions. Nonetheless, the incentives for agencies to address constitutional concerns administratively remain present, even if ordinary administrative law is not usually the mechanism by which such incentives are created.

The Court's failure to encourage administrative constitutionalism through ordinary administrative law contrasts markedly with the approach taken by the political branches. Congress and the President frequently impose statutory and regulatory restrictions on administrative decisionmaking that reflect their desire for agencies to attend to constitutional concerns. Such restrictions are particularly prevalent in the federalism context: Congress often requires agencies to consult with states before taking certain actions and to justify the imposition of particularly costly rules on states. ${ }^{81}$ The President has long sought, through executive orders, "to ensure that the principles of federalism established by the Framers guide the executive departments and agencies in the formulation and implementation of policies." ${ }^{12}$ The latest example of such federalism concerns is President Obama's recent memorandum imposing limits on when agencies can act to preempt state laws. ${ }^{83}$ Yet these statutory and regulatory demands that agencies consider constitutional values are not limited to federalism principles; they also surface in conjunction with individual rights. A notable example involves limitations on

involved application of constitutional jurisdictional requirements rather than ordinary administrative law.

${ }^{81}$ See, e.g., Unfunded Mandates Reform Act of 1995 (UMRA)§§201-202, 205,2 U.S.C. $\$ \$ 1531-1532,1535$ (2006) (stating "each agency shall ... assess the effects of Federal regulatory actions on State, local, and tribal governments" and "identify and consider a reasonable number of regulatory alternatives," selecting the "least costly"); Metzger, New Federalism, supra note 60, at 2056-57 (arguing that Congress, in addition to the Court, has emphasized "administrative procedure as a means of ensuring federal agencies consider state interests").

${ }^{82}$ Exec. Order No. 13,132, 3 C.F.R. 206 (1999), reprinted in 5 U.S.C. $\S 601$ (2006). Executive Order 13,132 replaced an earlier executive order promulgated by President Reagan, Exec. Order No. 12,612, 3 C.F.R. 252 (1987), which similarly sought to ensure agencies paid attention to federalism principles and required assessment of the federalism impact of proposed agency actions.

${ }^{83}$ Presidential Memorandum of May 20, 2009, 74 Fed. Reg. 24,693 (May 20, 2009). 
federal funds. A number of agencies have developed regulations to implement statutory prohibitions on federal funds being used in a racially discriminatory or otherwise constitutionally troubling fashion. ${ }^{84}$ A contemporary instance is the Office of Management and Budget's (OMB's) guidance on the use of federal stimulus funds, which provides that agencies must ensure grant recipients comply with federal antidiscrimination statutes and program requirements. ${ }^{85}$

A second point worth noting is simply the reality that administrative constitutionalism occurs. This point is most frequently made in regard to the work of the Office of Legal Counsel (OLC) and the Solicitor General, whose official responsibilities include analyzing constitutional issues arising in proposed legislation, agency actions, and litigation. ${ }^{86}$ Though these agencies are no doubt the most

${ }^{84}$ See, e.g., 34 C.F.R. $\$ 100$ (2008) (effectuating Title VI with respect to program or activity receiving financial assistance from Department of Education); 45 C.F.R. $\S 80$ (2008) (implementing same policy for Department of Health and Human Services). Similarly, agencies have adopted regulations to ensure equal treatment of faith-based organizations. For example, in Zobrest v. Catalina Foothills School District, the Supreme Court considered 34 C.F.R. $\$ 76.532$ (a)(1) (1992), which it explained "implements the Secretary of Education's understanding of (and thus is coextensive with) the requirements of the Establishment Clause." 509 U.S. $1,6 n .7$ (1993). Today, many such regulations provide for equal treatment of religious organizations. See, e.g., 45 C.F.R. $\$ 87.1$ (b) (2008) ("Religious organizations are eligible, on the same basis as any other organization, to participate in any Department program for which they are otherwise eligible."). A particularly interesting example is the Internal Revenue Service's interpretation of the tax code as prohibiting tax-exempt status for private schools that racially discriminated in admissions. See Olati Johnson, The Story of Bob Jones University v. United States: Race, Religion, and Congress' Extraordinary Acquiescence, in Statutory Interpretation Stories (Elizabeth Garrett et al. eds., forthcoming 2010) (manuscript at 1-3, on file with the Columbia Law Review) (discussing development of tax-exempt prohibition).

${ }^{85}$ Peter Orszag, Dir., Office of Mgmt. \& Budget, Memorandum for the Heads of Departments and Agencies, Initial Implementing Guidance for the American Recovery and Reinvestment Act of 2009 (Feb. 18. 2009), available at http://www.whitehouse.gov/omb/assets/memoranda fy2009/m09-10.pdf (on file with the Columbia Law Review).

${ }^{86}$ See Dawn E. Johnsen, Faithfully Executing the Laws: Internal Legal Constraints on Executive Power, 54 UCLA L. Rev. 1559, 1576-601 (2007) (analyzing OLC's role and critically assessing its approach to national security issues under the Bush administration); Morrison, supra note 70, at 1218-20 (discussing OLC's approach to constitutional avoidance); Cornelia T.L. Pillard, The Unfulfilled Potential of the Constitution in Executive Hands, 103 Mich. L. Rev. 
attuned to constitutional issues, they are not the sole location for constitutional interpretation within the executive branch. Scholars are beginning to document a number of instances in which other administrative agencies were at the forefront of developing new understandings of constitutional rights. William Eskridge and John Ferejohn, for example, have described how officials at the Equal Employment Opportunity Commission (EEOC) developed the view that pregnancy discrimination was sex discrimination. ${ }^{87}$ Sophia Lee has offered an account of the role that constitutional arguments played in the emergence of licensee equal employment and nondiscrimination requirements at the Federal Communications Commission (FCC) and other federal agencies. ${ }^{88}$ Like Eskridge and Ferejohn, Lee emphasizes the extent to which "administrative constitutionalism" - defined as "regulatory agencies' independent interpretation and implementation of constitutional law" - is "a recurring aspect of the modern American state." ${ }^{19}$ Anuj Desai has traced the development of the idea of communications privacy, now an established Fourth Amendment principle, to early decisions and practice within the post office. ${ }^{90}$ Law enforcement agencies provide further instances of administrative attention to constitutional requirements, with a notable example being the Department of Justice's U.S. Attorneys' Manual, which mandates disclosure policies for U.S. Attorneys' Offices in order to ensure compliance with the constitutional requirement that prosecutors disclose exculpatory evidence to defendants. ${ }^{91}$ Indeed, administrative constitutional

676, 702-17, 740-41 (2005) (describing the work of OLC and the Solicitor General and their effect on constitutional interpretation elsewhere in the executive branch).

${ }^{87}$ See William N. Eskridge \& John Ferejohn, American Constitutionalism: A

Republic of Statutes (forthcoming 2010) (manuscript ch. 1, at 11-12, on file with the Columbia Law Review).

${ }^{88}$ Sophia Z. Lee, Race, Sex, and Rulemaking: Administrative

Constitutionalism and the Workplace, 1960 to the Present, 96 Va. L. Rev.

(forthcoming 2010) (manuscript at 12-63, on file with the Columbia Law Review). For examples of the FCC's attention to constitutional concerns, see id. at 16-29.

${ }^{89}$ Id. at 3,5 .

${ }^{90}$ Anuj C. Desai, Wiretapping Before the Wires: The Post Office and the Birth of Communications Privacy, 60 Stan. L. Rev. 553, 568-84 (2007).

${ }^{91}$ See Dep't of Justice, U.S. Attorneys' Manual, Title 9: Criminal Resource Manual $\S 5.001$ (2006), available at http://www.usdoj.gov/usao/eousa/foia reading room/usam/title $9 / 5 \mathrm{mcrm}$.htm (on file with the Columbia Law Review) (stating a 
interpretation arguably occurs whenever government employees take actions that have potential constitutional significance - in short, all the time. ${ }^{92}$

\section{B. The Constitutional Common Law Character of Ordinary Administrative Law}

Several features of the appearances of constitutional law in administrative contexts merit particular emphasis and support the characterization of ordinary administrative law as an instance of constitutional common law. One is the largely indeterminate character of constitutional law when it surfaces. In some instances, such as the First Amendment licensing context, constitutional demands on administrative law are judicially specified with relative clarity. More commonly, however, the Court invokes general constitutional norms or standards and the scope of specific constitutional requirements remains uncertain. This indeterminacy is evident in procedural due process, given the Mathews v. Eldridge case-by-case balancing analysis and the fact that statutory and regulatory procedural protections often obviate the need for courts to determine the precise contours of procedural due process in administrative contexts. ${ }^{93}$ Such indeterminacy is especially true,

policy to "ensure timely disclosure of an appropriate scope of exculpatory and impeachment information"); Fred C. Zacharias, The Professional Discipline of Prosecutors, 79 N.C. L. Rev. 721, 762-63 (2001) (discussing internal office supervision, including agency manuals, as mechanism for controlling prosecutorial misconduct). On the whole, however, law enforcement agencies have been slow to adopt meaningful administrative constraints to guard against constitutional violations. See Sklansky, supra note 74, at 1272-73 (noting that development of guidelines limiting police discretion has been "sporadic, crisis-driven, and limited"); see also Debra Livingston, Police Discretion and the Quality of Life in Public Places: Courts, Communities, and the New Policing, 97 Colum. L. Rev. 551, 661-62 (1997) (noting areas in which police guidelines have been adopted and continued resistance to such administrative approaches).

${ }^{92}$ See David A. Strauss, Presidential Interpretation of the Constitution, 15 Cardozo L. Rev. 113, 114 (1993) [hereinafter Strauss, Presidential Interpretation] (noting the executive branch often must engage in constitutional interpretation to determine limits of its everyday authority).

${ }^{93}$ Mathews v. Eldridge, 424 U.S. 319, 334-35 (1976); see supra text accompanying notes 24-26 (discussing procedures used for administrative hearings 
however, of separation of powers and federalism principles invoked by courts or the political branches to justify ordinary administrative law doctrines and decisions. Little doubt exists, for example, that under existing case law courts do not violate either Article I or Article III when they interpret ambiguous statutes, that Congress could delegate broad power to administrative agencies to regulate major economic sectors without closely detailed guidance, or that Congress could preempt broad swaths of state law through regulatory statutes. As a result, doctrines such as Chevron and insistence on clear congressional authorization of broad delegations or preemptive effect are hard to categorize as constitutionally mandated. ${ }^{94}$ Instead, they are best described as constitutionally inspired requirements that reflect these general constitutional principles, while the exact nature of their constitutional underpinnings remains unspecified.

This indeterminate character is reinforced by the tacit quality of much constitutionalism in administrative law. As noted above, the Court rarely discusses the constitutional underpinnings of ordinary administrative law doctrines in any detail, and today often makes no reference whatsoever to the constitutional dimensions of its administrative law decisions. ${ }^{95}$ Why the Court is so reluctant to acknowledge the role played by constitutional concerns in the development of ordinary administrative law is somewhat of a puzzle. Resistance to openly acknowledging constitutional indeterminacy is

and constraints on discretion in administrative licensing and prior restraint regimes that affect First Amendment rights).

${ }^{94}$ See Barron \& Kagan, supra note 54, at 215 ("Congress has ultimate authority over whether and when Chevron deference should operate."); Merrill \& Hickman, supra note 55, at 866-67, 915 ("Chevron does not suggest that the nondelegation doctrine or any other principle of separation of powers compels this outcome."); Metzger, New Federalism, supra note 60, at 2048-52 (discussing Congress's wide regulatory authority under current doctrine and noting Court's failure to invoke express federalism curbs in recent cases involving agencyadministered statutes). Indeed, some scholars have argued that the Chevron doctrine is in fact constitutionally suspect. See Farina, supra note 50, at 487-98 (arguing Chevron deference in fact raises separation of powers concerns and is at odds with history of delegation doctrine); Jonathan T. Molot, The Judicial Perspective in the Administrative State: Reconciling Modern Doctrines of Deference with the Judiciary's Structural Role, 53 Stan. L. Rev. 1, 73-75 (2000) (arguing Chevron deference undermines the structural constitutional role originally assigned the judiciary).

${ }^{95}$ See supra text accompanying notes $18,23,48-50$ 
not ultimately a plausible explanation, given the extent to which the Court has embraced such indeterminacy in other aspects of constitutional analysis and in its application of the constitutional canons, a point discussed further below. ${ }^{96}$ A more likely cause is the Court's increased resistance to independent federal court lawmaking, a resistance also evident in the decline of implied rights of action and curtailment of federal common law. ${ }^{97}$ No doubt the Court's greater insistence on judicial supremacy in constitutional interpretation is also playing a role. Administrative law decisions are replete with references to Congress's ability to control - and in particular reduce the substantive and procedural requirements that govern agency action. ${ }^{98}$ From a judicial supremacy perspective, such congressional authority is difficult to square with an understanding of ordinary administrative law as having a constitutional component. Whatever the cause, the effect of the Court's refusal to openly acknowledge the role constitutional concerns play in fashioning administrative law is to leave the scope of the constitutional core of ordinary administrative law unclear.

An additional factor that obscures the boundaries between constitutional law and ordinary administrative law is the occasional reciprocal nature of their relationship. Not only do constitutional concerns underlay much ordinary administrative law, but ordinary

${ }^{96}$ See infra text accompanying notes $146-150$.

${ }^{97}$ See supra text accompanying notes 9-11; see also Alexander v. Sandoval, 532 U.S. 275, 293 (2001) (limiting implied right of action); Semtek Int'l, Inc. v. Lockheed Martin Corp., 531 U.S. 497, 508 (2001) (applying federal common law, but finding claim preclusion "classic case for adopting, as the federally prescribed rule of decision, the law that would be applied by state courts in the State in which the federal diversity court sits"); Paul Lund, The Decline of Federal Common Law, 76 B.U. L. Rev. 895, 899 (1996) (arguing the Court has restricted federal common lawmaking power by holding, contrary to prior case law, that "state law rather than federal common law governs certain issues," and by "requiring federal courts to incorporate state law rules as federal law even when federal common law" governs).

${ }^{98}$ See Vt. Yankee Nuclear Power Corp. v. Natural Res. Def. Council, Inc., 435 U.S. 519, 523-24, 548 (1976) (emphasizing that the APA represented the maximum procedural requirements "Congress was willing to have courts impose upon agencies in conducting rulemaking procedures" and castigating additional judicial procedural impositions as illegitimately "interfering with the process prescribed by Congress"); see also Webster v. Doe, 486 U.S. 592, 599-603 (1988) (noting Congress's ability to preclude judicial review). 
administrative schemes and requirements in turn can inform judicial understandings of what the Constitution requires. Under Mathews balancing, procedural due process analysis puts a thumb on the scale in favor of existing procedures being deemed constitutionally sufficient by framing the inquiry as the extent to which additional procedures would add to the accuracy of agency determinations. ${ }^{99}$ Similarly, an administrative complaint mechanism can offer very different relief from that available under Bivens - and in particular, no opportunity for money damages - and yet suffice for the Court to conclude that an individual's constitutional rights are satisfied. ${ }^{100}$ Alternatively, in some cases the Court may use existing administrative requirements to define the content of constitutional requirements. Of particular relevance here is Miranda: The constitutional warnings there required by the Court were not its own independent creation, but instead were the procedures the FBI had devised to ensure that confessions were not coerced. ${ }^{101}$ Another example emerges from the context of institutional reform litigation, in which successful programmatic initiatives become identified as remedies for constitutional violations through their incorporation in

${ }^{99}$ Mathews v. Eldridge, 424 U.S. 319, 335 (1976). While the Court has insisted that legislatively provided procedures cannot be the measure of all the process that is due, see Cleveland Bd. of Educ. v. Loudermill, 470 U.S. 532, 541 (1985) ("The right to due process is conferred, not by legislative grace, but by constitutional guarantee."), this analytic framing of the inquiry takes the government's provided procedures as the baseline against which additional requirements must be justified, rather than fostering a more independent judicial assessment of what types of procedures are appropriate given the interests involved.

${ }^{100}$ For a recent example, see Correctional Services Corp. v. Malesko, 534 U.S. 61,74 (2001), where the Court noted that the inmates in question had the alternative of pursuing "injunctive relief and grievances filed through the [Bureau of Prisons'] Administrative Remedy Program (ARP)." For a discussion of two earlier cases, Schweiker v. Chilicky and Bush v. Lucas, see supra note 28.

${ }^{101}$ See Miranda v. Arizona, 384 U.S. 436, 483-86 (1966) (citing letter from FBI describing Bureau practice of issuing warning at beginning of interview, including "right to say nothing and a right to counsel, and that any statement [suspect or person under arrest] does make may be used against him in court" as well as "right to free counsel"); see also Sheldon H. Elsen \& Arthur Rosett, Protections for the Suspect Under Miranda v. Arizona, 67 Colum. L. Rev. 645, 653 (1967) (arguing that FBI practice actually differed with respect to right to counsel during interrogations, and that "FBI experience merited deeper probing than it received" from the Court). 
consent decrees. ${ }^{102}$ More generally, the Solicitor General is an influential litigant at the Supreme Court, and thus the federal government's accounts of its administrative needs and the impact of constitutional protections is likely to be taken seriously by the Court in setting the boundaries of constitutional rights. ${ }^{103}$ This role of ordinary administrative law and administrative practice in setting the scope of constitutional requirements is of a piece with the numerous ways in which constitutional law has bent and transformed in response to the institutional and regulatory needs of the modern administrative state. ${ }^{104}$

A final feature of note is the evolving nature of ordinary administrative law, particularly administrative law as applied by the courts. ${ }^{105}$ Despite occasional efforts by the Court and commentators

${ }^{102}$ See David Zaring, National Rulemaking Through Trial Courts: The Big Case and Institutional Reform, 51 UCLA L. Rev. 1015, 1047-62 (2004) (identifying housing and prison litigation as two instances in which this phenomenon has occurred); see also Charles F. Sabel \& William H. Simon, Destabilization Rights: How Public Law Litigation Succeeds, 117 Harv. L. Rev. 1015, 1016-52 (2004) (arguing that experimentalist administrative methods, in particular benchmarking, performance measurement, and monitoring, are increasingly being required in consent decrees as mechanisms for remedying constitutional violations).

${ }^{103}$ See Pillard, supra note 86, at 689 ("Even when the Supreme Court is poised to decide an issue, the constitutional views voiced by the executive can shape the Court's view.").

${ }^{104}$ Several examples exist, including the rejection of meaningful limits on congressional delegations; acceptance of administrative agencies' combining legislative, executive, and adjudicatory powers and novel structures; and massive expansion in the scope of federal regulatory authority. For two differing perspectives on the constitutionality of the modern administrative state, compare Gary Lawson, The Rise and Rise of the Administrative State, 107 Harv. L. Rev. 1231,1231 (1994) ("The post-New Deal administrative state is unconstitutional ... ."), with Peter L. Strauss, The Place of Agencies in Government: Separation of Powers and the Fourth Branch, 84 Colum. L. Rev. 573, 579 (1984) [hereinafter Strauss, Place of Agencies] (arguing modern administrative agencies are compatible with constitutional principles). Such accession to administrative imperatives is also evident in regard to individual rights, as, for instance, in the acceptance of lower Fourth Amendment protections in administrative contexts. See Marshall v. Barlow's, Inc., 436 U.S. 307, 313, 320-21 (1978) (noting the closely regulated exception to the warrant requirement and emphasizing lower standard for establishing probable cause even in other contexts).

105 The executive branch's approach to administrative law has also changed markedly over the years, most notably with the advent of Executive Order 12,866 and regulatory review, but for purposes of connecting to discussions of 
to posit a static and statutorily based account of administrative law, ${ }^{106}$ any such account fails to capture much of current administrative law doctrine. Instead, a dominant feature of ordinary administrative law is its common law and thus evolving character. ${ }^{107}$ This evolving character is especially evident in regard to the standards and availability of judicial review under the APA. The Court not only has intensified arbitrary and capricious review over time and further refined its Chevron doctrine, it has also dramatically expanded the range of persons who can challenge agency action. Moreover, the Court's rules with respect to timing and preclusion of judicial review are overwhelmingly common law-derived, rather than statutorily determined, and as a result have also developed over time. ${ }^{108}$ Such an evolutionary process is equally apparent with respect to the APA's procedural requirements for informal rulemaking, with current requirements of notice and agency response to comments far

constitutional common law my focus here is more on the evolving cast of judicial doctrine. See generally Executive Order 12,866, 58 Fed. Reg. 51735 (Sept. 30, 1993).

${ }^{106}$ See Dir., Office of Workers' Comp. Programs v. Greenwich Collieries, 512 U.S. 267, 272 (1994) (arguing the APA must be interpreted according to its meaning when adopted in 1946); Vt. Yankee Nuclear Power Corp. v. Natural Res. Def. Council, Inc., 435 U.S. 519, 524 (1978) (arguing courts lack power to impose procedural requirements not required by the APA, other statutes or regulations, or the Constitution); see also John F. Duffy, Administrative Common Law in Judicial Review, 77 Tex. L. Rev. 113, 115 (1998) (acknowledging the common law character of much of administrative law but arguing administrative law is becoming increasingly statutory and praising this development).

${ }^{107}$ See Jack M. Beermann, Common Law and Statute Law in US Federal Administrative Law, in Administrative Law in a Changing State: Essays in Honour of Mark Aronson 45, 45-47 (Linda Pearson et al. eds., 2008) (arguing that federal courts behave as common law courts when dealing with administrative law issues); Kenneth Culp Davis, Administrative Common Law and the Vermont Yankee Opinion, 1980 Utah L. Rev. 3, 3-10 (arguing that courts, including the Supreme Court, have created administrative common law throughout the twentieth century).

${ }^{108}$ See Richard B. Stewart, The Reformation of American Administrative Law, 88 Harv. L. Rev. 1667, 1723-56 (1975) (noting the Court's conception of standing and participation rights in administrative law cases has expanded over time); see also Merrill, Capture Theory, supra note 39, at 1039-44, 1074-83 (tracing expansion and subsequent contraction in doctrines affecting the availability of judicial review). 
exceeding what the text of the APA suggests was originally expected. ${ }^{109}$

Constitutional concerns with unchecked agency power underlay all these judicial developments. ${ }^{110}$ Expanded rulemaking procedures and greater court access, along with heightened substantive scrutiny, helped guard against otherwise unaccountable agency abuses of delegated power. ${ }^{111}$ But tying the evolution of ordinary administrative law solely to constitutional concerns and judicial development ignores the degree to which this evolution is also politically driven. Statutes like the Freedom of Information Act (FOIA) $)^{112}$ and government in the sunshine requirements ${ }^{113}$ embodied

${ }^{109}$ See 5 U.S.C. $\$ 553(\mathrm{~b})$-(c) (2006) (requiring mere "description of the subjects and issues involved" and stating "concise general statement of [a rule's] basis and purpose" will suffice); Am. Radio Relay League v. FCC, 524 F.3d 227, 245-47 (D.C. Cir. 2008) (Kavanaugh, J., concurring in part, concurring in the judgment in part, and dissenting in part) (noting judicial interpretation of $\S 553$ 's requirements does not comport with the text of the APA); Jack M. Beermann \& Gary Lawson, Reprocessing Vermont Yankee, 75 Geo. Wash. L. Rev. 856, 882-900 (2007) (arguing a number of current rulemaking requirements go beyond $\S 553$ 's text).

${ }^{110}$ See supra text accompanying notes 39-47.

111 See Stewart, supra note 108, at 1711-60 (analyzing changes as representing a transformation in judicial review to focus on ensuring that all affected interests are fairly represented and considered by administrative agencies). Courts emphasized the connection between enhanced notice and participation requirements and checks on agency decisionmaking, see, e.g., Conn. Light \& Power v. Nuclear Regulatory Comm'n, 673 F.2d 525, 530-31 (D.C. Cir. 1982); United States v. Nova Scotia Food Prods. Corp., 568 F.2d 240, 251-53 (2d Cir. 1977), as well as at times invoked seemingly due process-based concerns of fundamental fairness, see, e.g., Pension Benefit Guar. Corp. v. LTV Corp., 875 F.2d 1008, 1020-21 (2d Cir. 1989), rev'd, 496 U.S. 633 (1990). Although express invocations of fundamental fairness in the rulemaking context have not fared well at the Court, see Pension Benefit Guar. Corp., 496 U.S. at 655-56; Vermont Yankee, 435 U.S. at 541-43, the Court has made little effort to curb $\S 553$ 's expansion, see Long Island Care at Home, Ltd. v. Coke, 551 U.S. 158, 174-75 (2007) (accepting logical outgrowth rule and its emphasis on "fair notice"); Metzger, Vermont Yankee, supra note 39, at 161-63.

112 Pub. L. No. 89-487, 80 Stat. 250 (1966) (codified as amended at 5 U.S.C. $\S$ $552(2006))$.

${ }^{113}$ See, e.g., Government in the Sunshine Act, Pub. L. No. 94-409, 90 Stat. 1241 (1976) (codified as amended at 5 U.S.C. $\$ 552(\mathrm{~b}), 557(\mathrm{~d})$ (2006)); Federal Advisory Committee Act, Pub. L. No. 92-463, 86 Stat. 770 (1972) (codified as amended at 5 U.S.C. App. II §1-15 (2006)). 
new political demands for open government that may have catalyzed judicial procedural developments. ${ }^{114}$ Similarly, the norm of expert, informed decisionmaking embodied in the reasoned explanation requirement traces back to the creation of the civil service and protections for administrative independence from politics in the formative period of the national administrative state. ${ }^{115}$ Over the years this norm has been reinforced by a vast array of other measures - prime among them the APA, but also substantive statutory provisions that demand a scientific basis for regulations and provisions creating agency structures that give a prominent role to professionals and substantive expertise. ${ }^{116}$ Agencies also often voluntarily adopt regulatory requirements that limit their discretion and expand procedural protections. ${ }^{17}$ These statutory and regulatory enactments sometimes reflect the political branches' understandings of what the Constitution demands. But they are more clearly "constitutional" in the sense of embodying basic contemporary

114 See Peter L. Strauss, Statutes That Are Not Static - The Case of the APA, $14 \mathrm{~J}$. Contemp. Legal Issues 767, 788-90, 796-99 (2005) (arguing that FOIA provided statutory support for judicial expansion of APA requirements and noting that Congress also enacted other, statute-specific hybrid procedures).

115 See Stephen Skowronek, Building a New Administrative State: The Expansion of National Administrative Capacities, 1877-1920, at 78-210 (1982) (describing progressive emphasis on expertise and opposition to the spoils system, and gradual expansion of merit-based civil service).

${ }^{116}$ See, e.g., 42 U.S.C. $\$ \$ 7408-7409$ (2006) (requiring that the EPA promulgate national air quality standards based on criteria that reflect latest scientific knowledge); 21 C.F.R. $\$ \$ 14.100,14.80$ (1986) (listing standing advisory committees at the FDA and qualifications for membership).

${ }^{117}$ See, e.g., FDA's Development, Issuance, and Use of Guidance Documents, 62 Fed. Reg. 8961 (Feb. 27, 1997), adopted and amended in FDA Accountability and Modernization Act, 21 U.S.C. $\$ 371(\mathrm{~h})$ (2006); 1 Richard J. Pierce, Jr., Administrative Law Treatise $\S 7.10$, at 504 (4th ed. 2002) [hereinafter Pierce, Administrative Law Treatise] (noting many agencies have issued rules obliging them to use notice-and-comment rulemaking for matters involving "public property, loans, grants, benefits, or contracts," despite the APA's exemption of these matters from rulemaking requirements); Rachel E. Barkow, Institutional Design and the Policing of Prosecutors: Lessons from Administrative Law, 61 Stan. L. Rev. 869,891 (2009) (noting most agencies follow the APA's separation of functions requirements whenever imposing punishment, even if not required by terms of the APA). For a recent discussion of this phenomenon, see Elizabeth Magill, Foreword, Agency Self-Regulation, 77 Geo. Wash. L. Rev. 859 (2009). 
normative commitments with respect to how government should operate. ${ }^{118}$

The net result of these features is that a good deal of ordinary administrative law could be characterized as constitutional common law. As Monaghan defined it, constitutional common law has two core components: the specification of requirements that are not themselves constitutionally mandated but serve to implement constitutional demands; and a role for the political branches in specifying the shape that these requirements take. ${ }^{119}$ Ordinary administrative law reflects the same characteristics. Its doctrines are constitutionally rooted but not constitutionally required, and emerge over time in a reciprocally informing fashion. Most significantly, Congress enjoys extensive power to control the contours of ordinary administrative law notwithstanding its constitutional dimensions. ${ }^{120}$ To be sure, there may be limits to such congressional authority; efforts by Congress to exempt agencies wholesale from duties of explanation or to preclude judicial review of broad swaths of agency action would likely face judicial resistance. ${ }^{121}$ But those are general systemic constraints that leave Congress broad discretion to reshape

118 They are thus arguably examples of what Professors William Eskridge and John Ferejohn call "small-c constitutional law," or what Ernest Young recently described as "the constitution outside the Constitution." See Eskridge \& Ferejohn, supra note 87 , intro., at 7-17 (describing small "c" constitutional law as super statutes and their interpretation and implementation by administrative agencies in response to public norms and needs); Ernest A. Young, The Constitution Outside the Constitution, 117 Yale L.J. 408, 411-14, 447 (2007) (arguing "much of the law that constitutes our government and establishes our rights derives from legal materials outside the Constitution itself," in particular given the extent to which "the Constitution permits basic constitutive questions to be answered by subconstitutional norms"); see also Tom Ginsburg, On the Constitutional Character of Administrative Law 2-3 (May 7, 2009) (unpublished manuscript, on file with the Columbia Law Review), available at http://www.law.yale.edu/documents/pdf/CompAdminLaw/Tom Ginsburg CompAdLaw paper.pdf ("Along several dimensions, administrative law should be understood as more 'constitutional' than constitutional law.").

${ }^{119}$ See Monaghan, Constitutional Common Law, supra note 1, at 2-3.

120 The President and administrative agencies themselves also play an important role, but their participation is in the form of adding additional constraints rather than reducing statutory requirements. Magill, supra note 117, at 860-62.

${ }^{121}$ See Murphy, supra note 43, at 1127-34 (suggesting "elimination [of hard look review] would affect how courts interpret other means of judicial control which are rooted in the Constitution," in particular nondelegation doctrine). 
ordinary administrative law in particular contexts. ${ }^{122}$ Moreover, Congress has shown little interest in diluting ordinary administrative law in such an across-the-board fashion, and has at times added new constraints. ${ }^{123}$ Indeed, recently the political branches have been more overt than the courts in their efforts to use administrative law to address constitutional concerns. ${ }^{124}$

\section{IMPLICATIONS OF THE CONSTITUTIONAL CHARACTER OF ORDINARY ADMINISTRATIVE LAW}

Recognizing the linkages between ordinary administrative law and constitutional law has several important implications for the debate over constitutional common law. Critiques of constitutional common law are often premised on the assumption that a clear divide exists between ordinary law and constitutional law, but as a descriptive matter that divide does not exist in the administrative law context. Perhaps more importantly, as a normative matter the constitutional common law status of ordinary administrative law has much to commend it. The real weakness in the Court's jurisprudence is not its intermixing of constitutional law and ordinary administrative law, but rather its failure to embrace judicially enforced administrative constitutionalism more thoroughly and overtly.

${ }^{122}$ Cf. Richard H. Fallon, Jr. \& Daniel J. Meltzer, New Law, NonRetroactivity, and Constitutional Remedies, 104 Harv. L. Rev. 1731, 1778-79, 1787-91 (1991) (arguing that while "the aspiration to effective individual remediation for every constitutional violation represents an important remedial principle," Congress may constitutionally deviate from that goal provided it supplies "a system of constitutional remedies adequate to keep government generally within the bounds of law").

${ }^{123}$ See, e.g., 29 U.S.C. $\S 655$ (b), (f) (2006) (outlining procedure by which occupational health and safety standards are set, including provision by which, inter alia, interested persons can request an oral hearing, and standards must be justified by substantial evidence); supra text accompanying notes 112-114 (discussing FOIA and open government requirements added in the 1970s). That said, Congress has sought to reduce judicial review of administrative actions in particular contexts, immigration being a central one. See 8 U.S.C. $\$ 1252(\mathrm{a})(2)$ (2006) (outlining "matters not subject to judicial review").

124 See supra text accompanying notes 81-85. 


\section{A. The False Divide Between Constitutional and Nonconstitutional Law}

Constitutional common law has long been attacked as illegitimate. One prominent line of criticism argues that constitutional common law violates basic separation of powers and federalism principles of our constitutional system, which combine to limit the federal courts' independent lawmaking role. ${ }^{125}$ As the Court famously put the point in Erie Railroad Co. v. Tompkins, "there is no federal general common law." ${ }^{126}$ Of course, the Erie principle has not governed in anything near such absolute form, with the Court sanctioning development of federal common law in several contexts. ${ }^{127}$ Yet the Court has increasingly emphasized that such exceptions are "few and restricted, limited to situations where there is a significant conflict between some federal policy or interest and the use of state law" ${ }^{\prime 28}$ and are all subject to congressional override. ${ }^{129}$

${ }^{125}$ See Grano, supra note 9, at 102-03, 123-29 (1985) (assessing the legitimacy of the Court's "prophylactic rules - rules that can be violated without necessarily violating the Constitution" and concluding that in many instances such rules exceed the Court's constitutional authority); Thomas W. Merrill, The Common Law Powers of Federal Courts, 52 U. Chi. L. Rev. 1, 13-27 (1985) [hereinafter Merrill, Common Law] (objecting to lawmaking by federal courts on grounds of federalism, separation of powers, and electoral accountability); Schrock \& Welsh, supra note 9, at 1126-45 (1978) (arguing federal constitutional common law "runs seriously afoul" of federalism and separation of powers); see also Bradford R. Clark, Federal Common Law: A Structural Reinterpretation, 144 U. Pa. L. Rev. $1245,1248-49,1256-64,1269-71$ (1996) (outlining the constitutional argument against "open-ended federal common lawmaking by courts").

${ }^{126} 304$ U.S. 64, 78 (1938).

${ }^{127}$ See Tex. Indus., Inc. v. Radcliff Materials, Inc., 451 U.S. 630, 640-41 (1981) (arguing "uniquely federal interests" justify the development of federal common law where Congress has granted the courts authority to do so); see also Hart and Wechsler, supra note 14, at 607 ("No one today would seriously dispute that the body of federal law includes judge-made law. Most would further agree that such law involves the exercise of some degree of judicial policymaking discretion, rather than the straightforward application of federal statutory or constitutional enactments.").

${ }^{128}$ O'Melveny \& Myers v. FDIC, 512 U.S. 79, 87 (1994) (citations omitted) (internal quotation marks omitted).

${ }^{129}$ See Nw. Airlines, Inc. v. Transp. Workers Union of Am., 451 U.S. 77, 95 \& $n .34$ (1981) ("Federal common law is subject to the paramount authority of Congress." (citations omitted) (internal quotation marks omitted)). 
Hence, as a general matter courts can displace federal and state law only in the course of enforcing either the Constitution or some other binding federal enactment. In the case of constitutional common law, however, the constitutional rule applied by the courts is by definition provisional and subject to congressional revision, yet is used to trump state law. Some critics deny that the federal courts have the authority to impose a constitutional rule that is not actually constitutionally required. ${ }^{130}$

Constitutional common law has not lacked for defenders. ${ }^{131}$ Some scholars have sought to salvage at least portions of constitutional common law by arguing that the rules imposed actually are constitutionally required unless Congress imposes an adequate substitute "that provides roughly the same degree of protection for constitutional policies as the federal common law rule." ${ }^{132}$ A number

${ }^{130}$ See Grano, supra note 9, at 134 (arguing federal courts do not have authority to "impose implementing 'details' that are not constitutionally required"); see also Merrill, Common Law, supra note 125, at 54-56 ("[A] body of common law rules 'inspired' but not 'required' by the Constitution presents far more serious problems of legitimacy than Monaghan acknowledges."); Schrock \& Welsh, supra note 9, at 1131-45 (critiquing Monaghan's posited sources of authority for constitutional common law). A second line of criticism also leveled at constitutional common law is that the approach was insufficiently protective of constitutional rights, particularly by allowing Congress to revise judicial rules implementing constitutional requirements and encouraging the Court itself to interpret constitutional requirements minimally so as to leave room for experimentation. See id. at 1152-53, 1158-71 ("We believe it important to recognize that the constitutional common law can be promulgated to achieve the opposite result, a contraction of personal liberties.").

${ }^{131}$ Monaghan, of course, was one of these. His justifications for constitutional common law were largely pragmatic, emphasizing the benefits of the concept as a "satisfactory way to rationalize a large and steadily growing body of Court decisions," the Court's special institutional competence in fashioning understandings of the content of constitutional rights, and "a need for a uniform national definition of at least the significant dimensions" of constitutional liberties. Monaghan, Constitutional Common Law, supra note 1, at 19, 35-36. But he also justified it on grounds of constitutional principle, arguing that the possibility of congressional revision and dialogue addressed separation of powers and federalism concerns and underscoring that "constitutionally inspired common law ... is ... designed to effectuate policies found in the text and structure of the Constitution." Id. at 35.

${ }^{132}$ Merrill, Common Law, supra note 125, at 58; see also Michael C. Dorf \& Barry Friedman, Shared Constitutional Interpretation, 2000 Sup. Ct. Rev. 61, 76-85 
of others have insisted that institutional competency concerns, such as limits on the courts' ability to identify constitutional violations and enforce amorphous tests, are legitimate factors for the courts to consider and inevitably result in constitutional doctrines that differ in scope from the constitutional provisions they enforce. ${ }^{133}$ Sometimes the resultant doctrines are prophylactic and prohibit actions the Constitution might seem to allow; at other times, institutional concerns lead to underenforcement of constitutional requirements. ${ }^{134}$

This debate has played out most recently with respect to the constitutional canons of statutory interpretation. On the surface, this statutory interpretation context might seem quite different from Monaghan-style constitutional common law, which is expressly constitutional in its focus. But although arising with respect to statutory interpretation, the canons in fact represent a form of constitutional enforcement. Under the canons, the Court seeks to protect constitutional values through means such as presumptions, clear statement rules, and construction of statutes to avoid

(discussing Miranda and Dickerson in these terms and outlining permissible congressional responses); Grano, supra note 9, at 119-22, 130-32 (arguing some of Monaghan's examples of constitutional common law are actually mandatory constitutional rules).

${ }^{133}$ See, e.g., Fallon, Implementing, supra note 3, at 5-10, 37-41 (emphasizing extent to which the Court's function is to implement constitutional norms and justifying resultant deviations between constitutional doctrine and constitutional meaning); Berman, supra note 3, at 9, 15-16, 88-100 (distinguishing "constitutional doctrines that are simply judicial determinations of what the Constitution means from those conceptually distinct doctrinal rules that direct how courts - faced, as they inevitably are, with epistemic uncertainty - are to determine whether the constitutional meaning has been complied with"); Roosevelt, supra note 3 , at 1652 67 (discussing implications of "distinction between the Constitution itself and the rules that Courts apply in deciding cases"); Strauss, Prophylactic Rules, supra note 3, at 194-95, 207-08 (arguing it is "obviously legitimate" for courts to take their own institutional limitations into account when formulating constitutional doctrine).

${ }^{134}$ See Strauss, Prophylactic Rules, supra note 3, at 195-207 (discussing how "judge-made prophylactic rules" may exceed the requirements of the constitutional provisions on which they are based); see also Lawrence Gene Sager, Fair Measure: The Legal Status of Underenforced Constitutional Norms, 91 Harv. L. Rev. 1212, 1214-21, 1227 (1978) (arguing some constitutional norms are judicially underenforced for institutional competency reasons but remain fully binding on other government officials). 
constitutional doubts. ${ }^{135}$ Moreover, the parallel goes deeper, because implicit in the Court's application of the canons and efforts to address constitutional concerns through statutory interpretation is recognition that these efforts are subject to congressional revision, with Congress retaining power to overturn the Court's constitutionally inspired interpretations. ${ }^{136}$ Hence, the canons constitute another example of constitutional common law - constitutional or constitutionally inspired determinations that, while binding, are avowedly provisional in nature. ${ }^{137}$ Not surprisingly, therefore, some have criticized use of the canons as an illegitimate form of covert constitutional

${ }^{135}$ See Ernest A. Young, Constitutional Avoidance, Resistance Norms, and the Preservation of Judicial Review, 78 Tex. L. Rev. 1549, 1585 (2000) [hereinafter Young, Constitutional Avoidance] ("The normative values supporting the avoidance canon are constitutional in nature ...."); see also Dan T. Coenen, A Constitution of Collaboration: Protecting Fundamental Values with Second-Look Rules of Interbranch Dialogue, $42 \mathrm{Wm}$. \& Mary L. Rev. 1575, 1582-94, 1735-55 (2001) (describing a number of constitutional "second look" doctrines that emphasize the process the Court uses in reaching decisions and reflect a collaborative approach to constitutional interpretation, including constitutional common law and the constitutional canons as examples); Philip P. Frickey, Getting from Joe to Gene (McCarthy): The Avoidance Canon, Legal Process Theory, and Narrowing Statutory Interpretation in the Early Warren Court, 93 Cal. L. Rev. 397, 450-52 (2005) (arguing canon of constitutional avoidance is "a rule of constitutional adjudication"); Morrison, supra note 70, at 1212 ("The overarching norm implemented by the avoidance canon is that if Congress wants to legislate to the limits of its constitutional authority or in a manner that otherwise raises serious constitutional concerns, it must be clear about its intent to do so.").

${ }^{136}$ See Clark v. Martinez, 543 U.S. 371, 382 (2005) ("The canon [of

constitutional avoidance] is ... a means of giving effect to congressional intent, not of subverting it.").

${ }^{137}$ See John F. Manning, Clear Statement Rules and the Constitution, 110 Colum. L. Rev. 399, 401-02 (2010) [hereinafter Manning, Clear Statement Rules] (describing constitutional canons, including clear statement rules and the canon of avoidance, as the most frequent contemporary manifestation of constitutional common law); see also Dan T. Coenen, The Pros and Cons of Politically Reversible "Semisubstantive" Constitutional Rules, 77 Fordham L. Rev. 2835, 2843-44 (2009) (describing "clear statement" rule as "constitutional 'how' rule," whose substantive holding is subject to congressional revision); William $\mathrm{N}$. Eskridge, Jr. \& Philip P. Frickey, Quasi-Constitutional Law: Clear Statement Rules as Constitutional Lawmaking, 45 Vand. L. Rev. 593, 597 (1992) (categorizing the canons as form of quasi-constitutional law); Mark Tushnet, Subconstitutional Constitutional Law: Supplement, Sham, or Substitute?, $42 \mathrm{Wm}$. \& Mary L. Rev. $1871,1871 \& n .1$ (2001) (terming them subconstitutionalism). 
decisionmaking by which courts restrict Congress and rewrite statutes based on amorphous constitutional concerns as opposed to actual constitutional violations. ${ }^{138}$ In turn, defenders of the canons have invoked arguments akin to those raised to justify constitutional common law, in particular maintaining that the canons are no different in principle from much constitutional law and represent doctrinal mechanisms for enforcing constitutional norms that, due to limitations on the courts' institutional competency, are not easily directly judicially imposed. ${ }^{139}$

Underlying many of these attacks on constitutional common law whether launched earlier at Monaghan's defense of constitutional common law or more recently at the Court's expanded use of the constitutional canons - is a vision of the Constitution as having determinate limits as well as a binary, on/off character. ${ }^{140}$

${ }^{138}$ See Richard A. Posner, Statutory Interpretation - in the Classroom and in the Courtroom, 50 U. Chi. L. Rev. 800,816 (1983) (arguing effect of the canon is to create "judge-made constitutional penumbras" and thereby "enlarge the already vast reach of constitutional prohibition beyond even the most extravagant modern interpretation of the Constitution"); Frederick Schauer, Ashwander Revisited, 1995 Sup. Ct. Rev. 71, 86-89 ("The idea that the court is avoiding a constitutional decision [under the avoidance canon] is illusory. It is in fact making one ... without the necessity of the full statement of reasons supporting the constitutional decision."); see also William K. Kelley, Avoiding Constitutional Questions as a Three-Branch Problem, 86 Cornell L. Rev. 831, 860-64, 867-91 (2000) (noting concerns about constitutional penumbras voiced by Posner and Schauer and arguing the canons also illegitimately intrude on the President's Article II take care power).

${ }^{139}$ See Sunstein, Nondelegation, supra note 61, at 337-42 (suggesting canons operate as nondelegation principles); Young, Constitutional Avoidance, supra note 135, at 1585-87, 1591-93, 1603-06 (viewing canons as a "useful mechanism for realizing important constitutional values").

140 To some extent, Monaghan himself also accepted a distinction between constitutional and nonconstitutional law, distinguishing constitutional common law from, on the one hand, more pure Marbury-style constitutional interpretation and, on the other, ordinary federal common law. See Monaghan, Constitutional Common Law, supra note 1, at 30-34 (distinguishing Marbury-style review); id. at 11-13 (describing standard technique of deriving federal common law). Yet in setting out in essence a tripartite framework - constitutional interpretation, constitutional common law, and nonconstitutional law, including federal common law - and in acknowledging that the distinction between constitutional interpretation and constitutional common law was a matter of degree, see id. at 31 , Monaghan resisted the insistence on a clear constitutional/nonconstitutional demarcation. 
Governmental action either violates constitutional requirements or it does not; a judicially imposed requirement either is constitutionally mandatory or it is not. ${ }^{141}$ Wholly excluded is the possibility that no such clear divide between constitutional law and nonconstitutional law exists, that a given governmental action could implicate constitutional values in a way that merits judicial response yet does not provide a sufficient basis for a court to hold the action unconstitutional or to preclude congressional revision of judicial determinations. ${ }^{142}$ Ernest Young articulated this alternative vision in his defense of the constitutional canons, in which he rejected the binary model and argued instead that some constitutional requirements surface as "resistance norms" that "are best enforced through doctrinal tools that act in the context of statutory construction." 143

${ }^{141}$ For recent articulations of this constitutional vision, see Dickerson $v$. United States, 530 U.S. 428, 454 (2000) (Scalia, J., dissenting) (arguing that a decision is constitutional only if "the Constitution requires the result that the decision announces," thus rendering that decision "impervious to supersession by congressional legislation"); see also John F. Manning, Federalism and the Generality Problem in Constitutional Interpretation, 122 Harv. L. Rev. 2003, 2040 55 (2009) [hereinafter Manning, Federalism] (describing the Constitution as adopting federalism only in form of particular measures and rejecting reliance on general federalism principles in constitutional interpretation as illegitimately devaluing the specific compromises on federalism to which the Founders agreed).

142 Young, Constitutional Avoidance, supra note 135, at 1593-94. Interestingly, many defenses of constitutional common law evidence a similar acceptance of a divide between the constitutional and nonconstitutional. These defenses have sought to dramatically expand the boundaries of what qualifies as legitimately constitutional, but for the most part have not challenged the assumption that a meaningful divide exists between the constitutional and nonconstitutional. See, e.g., Dorf \& Friedman, supra note 132, at 78-80 (attempting to reconcile Miranda's constitutional status with its acceptance of alternative safeguards by reading Miranda's holding narrowly and emphasizing the legitimacy of shared constitutional interpretation); Roosevelt, supra note 3, at 1655-58, 1670 (arguing constitutional decision rules may deviate substantially from the operative meaning of the Constitution, but are nonetheless legitimate); Strauss, Prophylactic Rules, supra note 3, at 195-207 (arguing judicially imposed prophylactic rules are ubiquitous in constitutional law, rather than questioning the assumption that they must be fully constitutional to be legitimate).

${ }^{143}$ Young, Constitutional Avoidance, supra note 135, at 1593-94. Young also rejects the assumption that statutory interpretation should be "constitution-free," Schauer, supra note 138 , at 83 , arguing that "such an approach categorically excludes a source of statutory meaning which is no less legitimate than other 
The critics' view of constitutional law as having determinate limits and a binary character is descriptively false when it comes to administrative law. Far more accurate is Professor Young's resistance norms model, with general constitutional values and principles being enforced through nonconstitutional mechanisms such as statutory construction and administrative policysetting. ${ }^{144}$ As noted above, constitutional law frequently surfaces in ordinary administrative law in a highly indeterminate form; constitutional concerns shape administrative law doctrines and lie in the background of numerous administrative enactments, but often the precise scope of the constitutional requirements involved remains opaque. ${ }^{145}$

The indeterminacy of constitutional considerations in administrative settings is hardly unique. It is a commonplace that numerous core constitutional demands - due process, equal protection, freedom of speech - are broad enough to support a wide array of meanings. ${ }^{146}$ More importantly, constitutional adjudication is characterized by frequent resort to general constitutional values and principles. This is particularly true of separation of powers and federalism analyses, which are often driven more by general structural constitutional norms than by specific constitutional

'principles and policies' which frequently enter into interpretation." Young, Constitutional Avoidance, supra note 135, at 1591-92. Other scholars have similarly concluded that statutory interpretation is inseparable from constitutional law. See, e.g., Jerry L. Mashaw, Textualism, Constitutionalism, and the Interpretation of Federal Statutes, $32 \mathrm{Wm}$. \& Mary L. Rev. 827, 839 (1991) (arguing that all methodological commitments regarding statutory interpretation must ultimately be constitutionally grounded); Sunstein, Interpreting Statutes, supra note 57, at 411 (discussing necessity of referencing background principles in statutory interpretation).

${ }^{144}$ See supra text accompanying notes 59-61 (citing federalism and other constitutional concerns as basis for narrow interpretation of agency statutes).

${ }^{145}$ See, e.g., supra notes 93-104 and accompanying text.

${ }^{146}$ See, e.g., Laurence H. Tribe \& Michael C. Dorf, On Reading the Constitution 73-80 (1991) (noting importance of level of generality at which action is assessed in determining its constitutionality); Richard H. Fallon, Jr., The Supreme Court, 1996 Term - Foreword: Implementing the Constitution, 111 Harv. L. Rev. 54, 58 (1997) ("Reasonable citizens, lawyers, and judges differ widely about what methodology should be used to interpret the Constitution, about which substantive principles the Constitution embodies, and about how, in more practical terms, constitutional norms should be protected by doctrine."). 
requirements. ${ }^{147}$ General values also feature in individual rights contexts, with the Court balancing countervailing constitutional concerns in defining the scope of constitutional protections. ${ }^{148}$ Indeed, constitutional common law is sometimes defended as a mechanism for vindicating general constitutional values and polices. As Daniel Meltzer commented: "If federal courts have authority to formulate common law rules to help implement the broad purposes of statutory enactments, why should the same not be true when the source of inspiration is a set of values in the Constitution?"149

In the administrative law context, indeterminacy surfaces not just in establishing what the Constitution requires, but also in specifying when constitutional requirements end and nonconstitutional administrative law begins. A central feature of ordinary

${ }^{147}$ See Boumediene v. Bush, 128 S. Ct. 2229, 2258-62 (2008) (applying separation of powers principles to interpretation of the Suspension Clause); Gillian E. Metzger, Response, The Constitutional Legitimacy of Freestanding Federalism, 122 Harv. L. Rev. F. 98, 104-05 (2009), at http://www.harvardlawreview.org/media/pdf/LWebsite Content for JenniferForum Vol. 122Metzgermetzger.pdf (on file with the Columbia Law Review) (describing structural reasoning in separation of powers case law); see also Manning, Federalism, supra note 141, at 2068 (acknowledging Court's sometime use of a form of constitutional analysis in which "overall structure takes on a life of its own, providing the source for values that are attached to no particular clause of the document but are nonetheless enforceable as law," but critiquing this practice).

${ }^{148}$ See, e.g., Garcetti v. Ceballos, 547 U.S. 410, 420 (2006) (describing precedent on constitutional protection for employee speech as seeking "both to promote the individual and societal interests that are served when employees speak as citizens on matters of public concern and to respect the needs of government employers attempting to perform their important public functions"); Wyoming $v$. Houghton, 526 U.S. 295, 299-300 (1999) (describing Fourth Amendment test as "assessing, on the one hand, the degree to which [challenged action] intrudes upon an individual's privacy and, on the other, the degree to which it is needed for the promotion of legitimate governmental interests"); Planned Parenthood of Se. Pa. $v$. Casey, 505 U.S. 833, 875-79 (1992) ("The undue burden standard is the appropriate means of reconciling the State's interest [in potential life] with the woman's constitutionally protected liberty.").

${ }^{149}$ Daniel J. Meltzer, State Court Forfeitures of Federal Rights, 99 Harv. L. Rev. 1128, 1173 (1986); see also Monaghan, Constitutional Common Law, supra note 1, at 35 ("Constitutionally inspired common law ... [is] designed to effectuate policies found in the text and structure of the Constitution."); cf. Manning, Federalism, supra note 141, at 2005-09 (arguing the Court's invocation of freefloating federalism values in constitutional interpretation is at odds with its turn towards textualism and rejection of purposivism in statutory interpretation). 
administrative law is the absence of a clear divide between its constitutional and nonconstitutional aspects. To be sure, many ordinary administrative law requirements are clearly constitutional or statutory and regulatory in nature. But what is striking is how many core doctrines and administrative requirements are simultaneously constitutional and nonconstitutional, and these dimensions are too overlapping and interactive to be easily segregated. It is impossible to know, for example, how arbitrary and capricious scrutiny would have developed absent constitutional concerns with unchecked agency power that helped (openly at first, and more tacitly later) fuel development of current hard look review. It is equally impossible to know what shape constitutional doctrines, such as delegation doctrine or rationality review of administrative actions, would have taken were the APA not available to courts as a surrogate for addressing these separation of powers concerns. As noted above, the availability of such ordinary administrative law constraints - particularly ordinary administrative law constraints that the Court shaped to address tacit constitutional concerns - has allowed it to avoid addressing these constitutional issues directly. ${ }^{150}$

Ordinary administrative law thus challenges the image of constitutional law as substantially determinate as well as the closely associated assumption that a clear divide exists between constitutional and nonconstitutional law. This descriptive point carries normative implications. To begin with, it suggests that the critique of constitutional common law is based on an image of constitutional law that differs from how constitutional law actually operates. Constitutional law does not only surface in clearly demarcated contexts, but instead seeps into other areas of law, often operating in the background to shape development of nonconstitutional legal requirements.

Further, the implications of adopting a narrow and determinate vision of constitutional law could not be limited to the sphere of constitutional adjudication; instead, broad areas of what are assumed to be nonconstitutional law would also be significantly affected. Even if conceptually possible, segregating constitutional considerations from ordinary administrative law would be extremely disruptive of current practice. It would force courts to reconsider existing well-

${ }^{150}$ See supra text accompanying notes 33-35. 
established doctrines that appear to exceed their supposed statutory basis, and potentially to address constitutional questions that they have been able to avoid through reliance on ordinary administrative law. Worse, because of this reliance courts may face a gap in constitutional doctrine that they would need to overcome, limiting their ability to proceed incrementally and with flexibility. ${ }^{151}$ Moreover, any such effort at segregation would effectively end the common law method of fashioning administrative law doctrine; it is hard to see how a principled distinction can be drawn between ordinary administrative common law and constitutional common law, as the same issue of independent judicial lawmaking is presented in both. ${ }^{152}$ In any event, as a practical matter, constitutional concerns will likely creep back into administrative law doctrines unless the use of the common law method is more broadly curtailed. In short, rejecting constitutional common law would force a dramatic change in the practice and doctrines of ordinary administrative law.

\section{B. Justifying Administrative Constitutionalism}

The case for preserving the constitutional common law character of administrative law, however, goes well beyond avoiding disruption. My focus here will be on justifying judicial efforts to encourage administrative constitutionalism, and more specifically on using ordinary administrative law to force agencies to take constitutional values seriously in their decisionmaking. Under such an approach, courts would require agencies to expressly address serious constitutional concerns raised by their actions. Agencies failing to do so would face potential remand of their decisions as arbitrary and capricious - or, alternatively, a loss of deference on the grounds that their statutory interpretations were unreasonable. ${ }^{153}$

${ }^{151}$ See, e.g., supra text accompanying note 33 (noting the Court's precedents on procedural due process requirements for general policysetting date back to the turn of the century).

${ }^{152}$ See Monaghan, Constitutional Common Law, supra note 1, at 13-14 (treating constitutional common law as a species of federal common law).

${ }^{153}$ For prior suggestions in this vein, see Bamberger, supra note 73, at 111-23 (arguing agencies should be required to take constitutional concerns into account in their statutory interpretations, on pain of their interpretations being otherwise held unreasonable); Metzger, New Federalism, supra note 60, at 2104-07 (arguing for 
There are two grounds for focusing on this particular intersection between administrative law and constitutional law. First, it is the least accepted incorporation of constitutional concerns into administrative law. Although some have questioned whether particular measures, such as the Miranda rules, can be legitimately derived from the Constitution, the general proposition that governments may be required to adopt some administrative mechanisms to meet constitutional demands is not disputed. ${ }^{154}$ Similarly, federal court reliance, when possible, on ordinary administrative law in lieu of constitutional law is simply a manifestation of the rule that courts should reach constitutional questions only as a last resort, a deeply embedded and largely accepted judicial practice. ${ }^{155}$ Judicial development of ordinary administrative law doctrines to address constitutional concerns is more contentious, ${ }^{156}$ but it too has received judicial sanction in the past and at least is rarely overtly condemned. ${ }^{157}$ This approach is also closely akin to application of the constitutional avoidance canon, particularly when it manifests in judicial interpretation of administrative law statutes, and thus is not analytically so unusual. Indeed, the Court's use of constitutional

invalidation of agency action paying insufficient heed to federalism concerns under hard look review).

${ }^{154}$ See, e.g., Dickerson v. United States, 530 U.S. 428, 445-50, 453-54 (2000)

(Scalia, J., dissenting) (accepting Miranda warnings would be legitimate if constitutionally mandated, but denying they have such constitutional status); see also Lewis v. Casey, 518 U.S. 343, 349-50 (1996) (noting judicial ability to order administrative changes to remedy constitutional violations).

${ }^{155}$ See Ashwander v. Tenn. Valley Auth., 297 U.S. 288, 347 (1936) (Brandeis, J., concurring) ("The Court will not pass upon a constitutional question although properly presented by the record, if there is also present some other ground upon which the case may be disposed of."). See generally Lisa A. Kloppenberg, Avoiding Constitutional Questions, 35 B.C. L. Rev. 1003 (1994) (analyzing appropriateness of last resort rule in different contexts).

${ }^{156}$ See, e.g., Am. Radio Relay League, Inc. v. FCC, 524 F.3d 227, 246-48

(D.C. Cir. 2008) (Kavanaugh, J., concurring in part, concurring in the judgment in part, and dissenting in part) (emphasizing degree to which courts have, over time, expanded the APA's requirements beyond what its text requires).

${ }^{157}$ See supra text accompanying notes 39-47 (discussing Court's earlier willingness to acknowledge constitutional underpinnings of the reasoned decisionmaking requirement); see also Metzger, Vermont Yankee, supra note 39, at 160-62 (noting Vermont Yankee's rejection of judicial imposition of procedural requirements not contained in the APA has not led to questioning of hard look review or broad readings of procedural demands included in the APA). 
avoidance remains a vibrant part of its approach to statutory interpretation. ${ }^{158}$ In comparison, as demonstrated by Fox, the Court remains quite reluctant to use ordinary administrative law as a mechanism to encourage administrative constitutionalism. ${ }^{159}$

In addition, judicially enforced administrative constitutionalism stands out for its emphasis on shared constitutional implementation. Along with constitutional indeterminacy, this is a key characteristic of constitutional common law. This characteristic is less evident when administrative measures are used to satisfy constitutional requirements, an approach more in keeping with Marbury-style constitutional adjudication because courts remain largely responsible for determining whether particular measures are constitutionally adequate. Strands of shared constitutional interpretation are more present when courts develop administrative law doctrines in light of constitutional concerns. As noted, congressional enactments could trump many such judicially developed administrative law requirements, and the political branches have certainly imposed requirements on agencies that reflect constitutional concerns. ${ }^{160}$ Yet the invitation to engage in interbranch constitutional interpretation is much clearer when ordinary administrative law is used to force agencies to take constitutional values into account in their own decisionmaking. Development of administrative law doctrine to address constitutional concerns, by contrast, has been largely a judicial endeavor.

Despite its condemnation in Fox and general lack of overt employment by the Court, the use of ordinary administrative law to encourage administrative constitutional deliberation has much to commend it. This approach accords well with the administrative character of contemporary federal government and basic structural principles underlying our constitutional system, while at the same

${ }^{158}$ See Kelley, supra note 138 , at $832-33$ (noting that constitutional avoidance has "been repeatedly reaffirmed to the point that it has achieved rare status as a cardinal principle that is beyond debate" (internal quotation marks omitted)); Morrison, supra note 70, at 1192-93 \& n.10 (discussing centrality of the avoidance canon and providing numerous examples of its recent invocation).

${ }^{159}$ See FCC v. Fox Television Stations, Inc., 129 S. Ct. 1800, 1811 (2009) (rejecting argument that more stringent arbitrary and capricious review should apply where agency actions "implicate constitutional liberties").

${ }^{160}$ See supra text accompanying notes $98,112-118,120-124$. 
time ensuring effective constitutional enforcement and interfering less with political branch prerogatives than more direct judicial constitutional enforcement.

\section{Administrative Governance and Administrative}

Constitutionalism. - Perhaps the strongest argument for requiring agencies to take account of constitutional concerns is that doing so acknowledges the reality of modern administrative governance. Administrative agencies are today the primary decisionmakers in federal government. To be sure, agency actions are governed by the terms of authorizing statutes and they act subject to, at times, substantial congressional and presidential oversight. But these controls do not alter the reality that agencies wield considerable independent discretion in setting the shape of national policy and implementing federal programs.

As those primarily responsible for setting governmental policy, agencies should have an obligation to take constitutional norms and requirements seriously in their decisionmaking. Such an obligation can be inferred simply from the structure of our constitutional order, under which the Constitution governs all exercises of governmental authority and all government officials have an independent duty to support it. ${ }^{161}$ It could also be seen as a condition of delegation. The Court has made clear that broad congressional delegations of authority to administrative agencies are constitutional, but it has failed to adequately consider whether such delegations should come with constitutional strings attached. ${ }^{162}$ One such string should be that

${ }^{161}$ U.S. Const. art. VI, § 3, cl. 1; see Morrison, supra note 70, at 1223-28, 1259 (justifying executive branch use of the constitutional avoidance canon as following from "the executive branch's independent obligation to enforce the Constitution," although suggesting the canon is inappropriate where an "agency or other executive component interprets a statute it regularly administers and discusses with Congress"); Pillard, supra note 86, at 687-88 (discussing obligations and opportunities for executive constitutional interpretation); Sager, supra note 134, at 1227 (arguing government officials have a "legal obligation ... to avoid unconstitutional conduct," even if that means interpreting and upholding constitutional norms that are underenforced by the judiciary); see also 5 U.S.C. $\S$ 3331 (2006) (requiring federal employees to take oath of allegiance to the Constitution).

${ }^{162} \mathrm{Cf}$. Gillian E. Metzger, Privatization as Delegation, 103 Colum. L. Rev. $1367,1443-45,1456-61$ (2003) [hereinafter Metzger, Privatization as Delegation] 
congressional delegations not serve to remove constitutional constraints that would otherwise apply. ${ }^{163}$ Hence, if Congress has an independent and to some degree judicially enforceable obligation to take constitutional norms and values into account, as it does under the constitutional canons and other "second look doctrines," then the constitutional price of delegation should be that congressional delegates face this obligation too.

One critical difference between Congress and administrative agencies is that agencies lack independent lawmaking authority and can only exercise those powers delegated to them by Congress. ${ }^{164}$ This basic proposition underlies the well-established rule that a court will set aside an agency decision as arbitrary and capricious "if the agency has relied on factors which Congress has not intended it to consider." ${ }^{165}$ Preserving congressional legislative supremacy thus entails that courts not require agencies to consider constitutional concerns when Congress has expressly or impliedly excluded such factors from agency deliberations. But the instances in which consideration of constitutional concerns is incompatible with a congressional regulatory scheme will be rare. ${ }^{166}$ More common will

(arguing that in the privatization context the Court has erred in simply upholding delegations of power to private individuals without imposing an obligation to ensure such delegations are structured to adequately protect constitutional limits).

${ }^{163}$ See $i d$. at 1400-02 (arguing that structural principle of constitutional accountability requires government power not be delegated in a manner that allows constitutional limits to be evaded); see also Boumediene v. Bush, $128 \mathrm{~S}$. Ct. 2229, 2259 (2008) ("To hold the political branches have the power to switch the Constitution on or off at will ... would permit a striking anomaly in our tripartite system of government, leading to a regime in which Congress and the President, not this Court, say 'what the law is."' (quoting Marbury v. Madison, 5 U.S. (1 Cranch) 137, 177 (1803))).

${ }^{164}$ See Bowen v. Georgetown Univ. Hosp., 488 U.S. 204, 208 (1988) ("It is axiomatic that an administrative agency's power to promulgate legislative regulations is limited to the authority delegated by Congress."); Thomas W. Merrill, Rethinking Article I, Section 1: From Nondelegation to Exclusive Delegation, 104 Colum. L. Rev. 2097, 2109-14 (2004) ("It is hornbook law among administrative lawyers that an agency has the power to issue binding legislative rules only if and to the extent Congress has authorized it to do so." (internal quotation marks omitted)).

${ }^{165}$ Motor Vehicle Mfrs. Ass'n v. State Farm Mut. Auto. Ins. Co., 463 U.S. 29, 43 (1983).

${ }^{166}$ Such incompatibility might well exist if the constitutional claim at issue targeted the agency's very authority to act, for example a separation of powers 
be occasions in which taking constitutional values into account may change the shape of federal regulation and perhaps make it somewhat less effective in achieving congressional regulatory goals. In such contexts, agency consideration of constitutional values absent congressional instruction to the contrary should still be legitimate. Congress might well accept a trade-off of regulatory effectiveness for greater protection of constitutional values. Indeed, Congress arguably did so expressly in the very statute at issue in Fox, which instructs the FCC not to engage in censorship or "interfere with the right of free speech." ${ }^{167}$ At any rate, the assumption that Congress would do so seems little different from the assumption of congressional constitutional sensitivity that underlies judicial application of the canons. ${ }^{168}$ More importantly, given the central role of the Constitution in our governmental structure, unless Congress indicates to the contrary, the default presumption should be that Congress intends administrative agencies to consider relevant constitutional values in their decisionmaking. ${ }^{169}$ The importance of constitutional

challenge to the constitutionality of the agency's structure or to Congress's delegation of certain responsibilities to the agency. But exclusion of such challenges leaves a wide array of constitutional claims, including those relating to individual rights or federalism principles, potentially within the agency's purview. 16747 U.S.C. $\$ 326$ (2006); see Note, Communications Act - Scope of Arbitrary and Capricious Review, 123 Harv. L. Rev. 352, 359 (2006) (arguing that due to $\S 326$, "the constitutional integrity of the shift in the FCC's enforcement policy became a 'relevant factor' and 'an important aspect of the problem' being addressed by the agency"). Justice Breyer made a similar point in his Fox dissent, stating that he was not "claiming that agencies must always take account of possible constitutional issues when they formulate policy ... . but the FCC works in the shadow of the First Amendment." FCC v. Fox Television Stations, Inc., $129 \mathrm{~S}$. Ct. 1800, 1834-35 (2009) (Breyer, J., dissenting).

${ }^{168}$ But see Morrison, supra note 70, at 1222 (suggesting criticism of the avoidance canon as not tracking legislative intent "seems all the more forceful as applied to the executive branch").

${ }^{169}$ See Strauss, Presidential Interpretation, supra note 92, at 114 ("Almost always Congress does not intend to authorize the executive to violate the Constitution; rather, the best interpretation ... is [one] that ... implicitly incorporates the constitutional limit."); see also Morrison, supra note 70, at 1212-13 (arguing, in defending executive branch application of the canon of constitutional avoidance, that actual congressional intent is irrelevant when the canon is viewed as a mechanism for constitutional enforcement); cf. Gregory v. Ashcroft, 501 U.S. 452, 460-64 (1991) (insisting that Congress must have clearly indicated its intention to 
adherence and enforcement justifies requiring Congress to be clear if it intends agencies to act without considering significant constitutional issues raised by their actions. ${ }^{170}$

Requiring that agencies consider significant constitutional implications of their actions is far from the radical proposition Fox made it seem. Few deny that agencies - like all who exercise governmental power - have a legally enforceable duty to avoid violating the Constitution. True, the Fox Court sought to distinguish between this duty and an obligation to consider constitutional norms and principles more generally. Yet such a distinction is impossible to maintain in practice. Agencies must take constitutional norms and principles into account even to avoid actual constitutional violations, as they will often face situations in which the import of precedent and existing constitutional requirements is unclear. Moreover, it is at least arguable that "the executive branch's independent obligation to enforce the Constitution" may "entail enforcing [some constitutional] norms more robustly than the courts would."171

The real dispute in Fox is instead over whether agencies' obligation to consider constitutional concerns should be enforceable by courts under ordinary administrative law. Such judicial enforcement is not logically required by the proposition that agencies have an obligation to take constitutional concerns into account. Indeed, on a departmentalist approach that emphasizes each branch's independent responsibilities to interpret the Constitution, judicial enforcement might in fact seem an illegitimate extension of the courts' role. ${ }^{172}$ But this complaint ignores the special position of

alter the federal-state balance before a court should read a statute to have that effect).

${ }^{170}$ See Morrison, supra note 70, at 1212-27 (justifying administrative use of constitutional avoidance as a form of constitutional enforcement). But see Note, supra note 167, at 359 (arguing separation of constitutional analysis and arbitrary and capricious review is appropriate except when "the agency's organic statute ... commands explicit constitutional balancing").

${ }^{171}$ Morrison, supra note 70, at 1226.

172 For descriptions of departmentalism, see Post \& Siegel, Popular Constitutionalism, supra note 3, at 1031-33 (defining departmentalism as "the view that each of the three branches of the federal government possesses independent and co-ordinate authority to interpret the Constitution"); Keith E. Whittington, Extrajudicial Constitutional Interpretation: Three Objections and Responses, 80 N.C. L. Rev. 773, 782-83 (2002) ("The most significant historical and theoretical 
agencies. "An agency is neither Congress nor President nor Court, but an inferior part of government. Each agency is subject to control relationships with some or all of the three constitutionally named branches, and those relationships give an assurance ... that they will not pass out of control." ${ }^{173}$ Whereas judicial imposition of duties of deliberation on Congress and the President raise concerns of unwarranted judicial intrusion into the workings of constitutionally coequal branches, judicial supervision of administrative decisionmaking has long been thought pivotal for ensuring the constitutional legitimacy of administrative action. ${ }^{174}$

Thus, just as judicial review ensures that agencies adhere to congressional will and do not exceed or ignore statutory requirements, so too should judicial review ensure that agencies fulfill their obligations to consider significant constitutional implications of their actions. Importantly, judicial enforcement is only one route by which such policing of agencies' constitutional deliberations occurs; as discussed above, Congress and the President have been quite active in instructing agencies to give weight to constitutional concerns. ${ }^{175}$ It is hard to see why judicial encouragement of administrative constitutionalism should be more suspect than similar efforts by the political branches - especially given the courts' traditional role as constitutional enforcers.

That leaves the question of whether courts should enforce agencies' obligation to consider constitutional concerns through the medium of ordinary administrative law, instead of relying simply on

alternative to judicial supremacy, however, is departmentalism, or coordinate construction, which denies that any single interpreter is supreme.").

${ }^{173}$ Strauss, Place of Agencies, supra note 104, at 579.

${ }^{174}$ See supra text accompanying notes $36-38,40$ (discussing development of hard look review and early delegation precedent); see also Ethyl Corp. v. EPA, 541 F.2d 1, 68 (D.C. Cir. 1976) (Leventhal, J., concurring) ("Congress has been willing to delegate its legislative powers broadly - and courts have upheld such delegation because there is court review to assure that the agency exercises the delegated power within statutory limits ... ."); Louis L. Jaffe, Judicial Control of Administrative Action 320 (1965) ("The availability of judicial review is the necessary condition, psychologically if not logically, of a system of administrative power which purports to be legitimate, or legally valid.").

${ }^{175}$ See supra text accompanying notes $81-85$ (describing various laws and executive orders directing agencies to consider constitutional concerns in their decisionmaking). 
direct constitutional scrutiny. ${ }^{176}$ Using ordinary administrative law for this purpose has several advantages. To begin with, it underscores the argument that administrative constitutional deliberation should not be thought unusual, but rather seen as a standard feature of the reasoned decisionmaking requirement when an agency action implicates serious constitutional concerns. The fact that such concerns may not translate into a successful challenge on direct constitutional review does not mean that they do not merit consideration by the agency. In addition, the ordinary administrative law approach better accommodates the various factors, constitutional and nonconstitutional, that agencies must take into account in setting policy. Agencies cannot deliberate about constitutional concerns in a vacuum; instead, they must assess how to take these concerns into account while satisfying their statutory responsibilities and presidential policy priorities. ${ }^{177}$

Finally, using ordinary administrative law further reinforces the point that what is demanded is consideration of significant constitutional implications of agency action, not that constitutional concerns necessarily trump other relevant factors in an agency's deliberations. As a result, under ordinary administrative law principles, a careful explanation of how constitutional concerns were accommodated or why constitutional concerns are outweighed is all that an agency must supply. It then becomes the courts' responsibility to determine whether the agency's decision accords with constitutional requirements, assuming a justiciable constitutional challenge is also brought. This distinction demonstrates the error in Fox's claim that the APA mandates separation of constitutionality in distinguishing between a court's power to set aside "unlawful" agency action, which would encompass unconstitutional agency actions, and agency actions found to be "arbitrary [or] capricious."178

${ }^{176}$ As noted, see supra text accompanying notes $77-80$, direct constitutional scrutiny is the approach the Court now occasionally uses to foster greater administrative constitutional attentiveness.

${ }^{177}$ See Mashaw, Norms, Practices, supra note 55, at 508-10 ("Agencies must balance their more remote responsibilities as contributors to the unity of the legal order ... with their more proximate and primary responsibilities to the development of one segment of it.").

1785 U.S.C. $\$ 706(2)(\mathrm{A})(2006) ;$ FCC v. Fox Television Stations, Inc., 129 S. Ct. 1800,1812 (2009). 
Fox's argument misconstrues the nature of ordinary administrative law review of agency constitutional deliberations. The focus of such review is on determining that agencies gave consideration to the significant constitutional implications of their actions, leaving open the question of whether the agency's action in fact complies with constitutional demands. ${ }^{179}$

\section{Ensuring Adequate Constitutional Enforcement. - The} continued availability of independent constitutional scrutiny merits emphasis. Such scrutiny ensures that reliance on ordinary administrative review does not undermine judicial constitutional enforcement. Even if an agency reasonably opts to pursue a particular policy despite constitutional concerns, and hence satisfies the demands of ordinary administrative review, a court may still invalidate the policy as actually unconstitutional. ${ }^{180}$ Thus, skepticism that the executive branch will elevate its political agenda over constitutional considerations should not fuel opposition to the ordinary administrative law approach advocated here. ${ }^{181}$

In fact, however, encouraging agencies to take constitutional concerns into account is likely to prove a valuable mechanism for ensuring effective constitutional enforcement in administrative contexts. Administrative consideration will be particularly important

${ }^{179}$ See Note, supra note 167 , at 360 (arguing the "separation of arbitrary and capricious review and constitutional review into different subsections of the APA may support the conclusion that each subsection articulates different reasons for invalidating an agency action" but that "it seems fairly unsupportable and counterintuitive to suggest that $\S 706(2)$ (A) excludes any consideration of an agency's constitutional reasoning").

${ }^{180}$ Fox underscores the availability of such a challenge. $129 \mathrm{~S}$. Ct. at 1812 (stating the "lawfulness [of an agency action] under the Constitution is a separate question to be addressed in a constitutional challenge").

${ }^{181}$ See Pillard, supra note 86, at 699-702, 717 (noting core question is whether the executive can "engage in something other than opportunistic, situational constitutionalism through which lawyers advance whatever arguments support the president's immediate agenda"). Such skepticism is reinforced by the failures of the Bush Administration to give due weight to constitutional and other legal constraints in the national security context. For discussions, see Johnsen, supra note 86 , at 1564 ("The proposition that the President's own legal advisors can provide an effective constraint on unlawful action understandably engenders a high degree of skepticism - especially in light of recent events."). See generally Jack Goldsmith, The Terror Presidency (2007). 
in contexts where constitutional requirements are arguably judicially underenforced, such as federalism, delegation limits, or governmental funding restrictions. ${ }^{182}$ In addition, constitutional challenges frequently depend on complex factual determinations - for example, about the scope of the burden actually imposed by a proposed regulation, the availability of less burdensome alternatives, and the seriousness of the harm the government seeks to address. As Kenneth Bamberger observes, agencies have particular competence in investigating and assessing the factual basis that often underlies constitutional claims. ${ }^{183}$ Even if subsequent judicial scrutiny is needed to ensure that constitutional constraints are adequately enforced, that review will be enhanced by agency development of a factual record, the type of record agencies would need to produce to demonstrate they had considered the constitutional claims at issue. ${ }^{184}$

${ }^{182}$ See Metzger, New Federalism, supra note 60, at 2054 (arguing the Court addresses underenforced doctrines like federalism through administrative law to defer to Congress); Pillard, supra note 86, at 692-98 (providing examples of "executive constitutionalism" in various contexts marked by limited judicial review, such as foreign policy, national security, and immigration); see also Hein $v$. Freedom From Religion Found., Inc., 551 U.S. 587, 593 (2007) (denying taxpayer standing to challenge executive branch expenditures not mandated by Congress on Establishment Clause grounds).

${ }^{183}$ Bamberger, supra note 73 , at $96-99$; see also Pillard, supra note 86 , at 738 , $742,751-52$ (describing ability to take initiative as well as "distinctive, institutionally and factually grounded insight" as potential advantages of executive branch constitutionalism, but noting advantages are undermined by concentration of constitutional engagement in separate departments, in particular OLC and the Office of the Solicitor General). For a classic analysis of the role of adjudicatory facts in constitutional litigation, see Henry P. Monaghan, Constitutional Fact Review, 85 Colum. L. Rev. 229 (1985).

${ }^{184}$ See, e.g., Wyeth v. Levine, 129 S. Ct. 1187, 1201 (2009) (noting that although the Court "has not deferred to an agency's conclusion that state law is preempted[,] ... agencies ... have a unique understanding of the statutes they administer and an attendant ability to make informed determinations about how state requirements may pose an obstacle" to the full achievement of congressional purposes to which the Court will give weight, with the degree of weight given depending on the "thoroughness, consistency, and persuasiveness" of the agency's explanation (internal quotation marks omitted)); Lorillard Tobacco Co. v. Reilly, 533 U.S. 525, 556-66 (2001) (reviewing evidence compiled by state agency in concluding that state regulations banning outdoor advertising of smokeless tobacco and cigars satisfied Central Hudson requirement that restrictions on commercial speech not be based on speculation and conjecture, but holding the regulations 
Agencies also have the capacity to devise regulatory solutions that avoid raising constitutional issues in the first instance, whereas courts are limited to responding to regulatory choices made by others. Thus, an agency sensitive to the due process concerns raised by indefinite detention of deportable aliens might choose to forgo such detention altogether in lieu of an alternative approach, or decide to employ detention in only some contexts rather than across the board. ${ }^{185}$ To take another recent example, an agency might decline to preempt state measures so as not to intrude unnecessarily on state authority. ${ }^{186}$ Courts might, of course, impose similar limitations on agency authority, but some constitutional issues may not reach the courts and, at a minimum, agency restraint avoids the need for suit to ensure constitutional values are protected. ${ }^{187}$

nonetheless unconstitutional because the government had failed to show the regulations were not more extensive than necessary).

${ }^{185}$ See supra text accompanying notes $72-73$ (describing Immigration and Customs Enforcement's adoption of a more narrowly tailored approach to detention in response to judicial reversal of broader policy). Thus, the statement that an agency "lacks institutional competence to resolve the ... constitutionality of a statute," McCarthy v. Madigan, 503 U.S. 140, 147-48 (1992), is overbroad. Even if an agency lacks authority to deem a statute under which it acts facially unconstitutional, it can often eliminate or at least mitigate constitutional concerns through its implementation choices and in other ways bring its specialized expertise to bear on the question of constitutionality. See supra text accompanying notes 183-184.

${ }^{186}$ See Nixon v. Mo. Mun. League, 541 U.S. 125, 140 (2004) (noting federal agency refused to declare state statute prohibiting state subdivisions from providing telecom services to be preempted, relying in part on principle that Congress must speak clearly before restricting how a state can structure its government); see also Press Release, Office of the Press Sec'y, The White House, Memorandum for the Heads of Executive Departments and Agencies (May 20, 2009), available at http://www.whitehouse.gov/the press office/Presidential-Memorandum-RegardingPreemption (on file with the Columbia Law Review) ("Preemption of State law by executive departments and agencies should be undertaken only with full consideration of the legitimate prerogatives of the States and with a sufficient legal basis for preemption.").

${ }^{187}$ See, e.g., Hein, 551 U.S. at 593 (finding taxpayer does not have standing to challenge Office of Faith-Based Initiatives as violating Establishment Clause); Strauss, Presidential Interpretation, supra note 92, at 115-16 (noting "categories of decisions, in which the issue seldom ends up in court, the executive is less oriented to the courts' views and the question of executive autonomy in interpreting the Constitution arises," and describing said categories, such as intelligence activities). 
Of equal importance, agencies are able to adopt and implement far-reaching reforms that can be more effective than court-ordered relief in avoiding and remedying constitutional problems in administrative settings. Decisionmaking by professionals within an agency and external expert review are important checks on agency overreaching and arbitrary determinations, but courts are unlikely to impose such personnel measures on agencies unless required by statutes or existing agency regulations. ${ }^{188}$ Managerial reforms - such as better training and oversight of personnel or enhanced accountability measures - are often critical in addressing constitutional problems in institutional contexts, and are frequently judicially ordered in the context of institutional reform litigation. ${ }^{189}$ But such reforms may be most effective when they are developed internally rather than externally imposed. ${ }^{190}$ In addition, the Court has repeatedly signaled a reluctance to intrude upon federal agency management, insisting on addressing only specific agency actions instead of broader attacks on federal programs. ${ }^{191}$ Although court-

${ }^{188}$ See, e.g., Gillian E. Metzger, The Interdependent Relationship Between Internal and External Separation of Powers, 59 Emory L.J. (forthcoming 2010) (manuscript at 12-14, 19-20, 25-28, on file with the Columbia Law Review) (emphasizing importance of internal constraints in improving agency decisionmaking and guarding against executive branch overreaching but noting the Court's unwillingness to view such internal constraints as constitutionally required).

${ }^{189}$ See Malcolm M. Feeley \& Edward L. Rubin, Judicial Policy Making and the Modern State: How the Courts Reformed America's Prisons 16, 162-69 (1998) (describing increased professionalization and adherence to dominant national standards for prison administration as central to prison reform litigation); Sabel \& Simon, supra note 102, at 1067-73 (emphasizing importance of experimentalist institutional reform in which stakeholders in public institutions negotiate provisional outcome-based remedies, often leaving institutions broad discretion over implementation).

${ }^{190}$ See Susan Sturm, Second Generation Employment Discrimination: A Structural Approach, 101 Colum. L. Rev. 458, 475-78 (2001) (arguing externally imposed, rule-based solutions cannot successfully address certain structural and implicit forms of discrimination because external rules are not "sufficiently sensitive to context or integrated into ... day-to-day practice," discourage "proactive problem-solving," and create a "narrow focus on avoiding liability").

${ }^{191}$ See, e.g., Summers v. Earth Island Inst., 129 S. Ct. 1142, 1149-5I (2009) (requiring plaintiffs to identify actual and imminent injury from particular timber sale for which agency did not use notice and comment procedures in order to challenge general regulation exempting certain categories of sales from such 
ordered systemic relief remains available when necessary to ensure protection of constitutional rights, broad scale managerial reforms are far more likely to result from agency initiation than from judicial intervention. ${ }^{192}$

Agencies also hold potential as sites for public deliberation on and engagement with constitutional meaning. Much recent constitutional scholarship has focused on extrajudicial constitutional interpretation, particularly through the interaction of social movements with political actors. ${ }^{193}$ Agencies play a critical role in these contexts, engaging with the same groups and advocates as broad statutes and presidential statements are translated into concrete policies. ${ }^{194}$ But agencies represent a prime locus for public interaction with government more generally. Administrative officials

procedural requirements); Lujan v. Nat'l Wildlife Fed'n, 497 U.S. 871, 891 (1990) (rejecting effort to challenge federal government's general failure to adequately implement federal land statutes on grounds that "respondent cannot seek wholesale improvement of this program by court decree, rather than in the offices of the Department or the halls of Congress, where programmatic improvements are normally made").

${ }^{192}$ See Lewis v. Casey, 518 U.S. 343, 356-60 (1996) (noting importance of right of access to courts, but finding inmate could not pursue claim because could not show actual injury).

${ }^{193}$ The literature on popular constitutionalism and the role of social movements is voluminous. See, e.g., William N. Eskridge, Jr., Some Effects of Identity-Based Social Movements on Constitutional Law in the Twentieth Century, 100 Mich. L. Rev. 2062, 2064 (2002) ("Most twentieth century changes in the constitutional protections of individual rights were driven by or in response to the great identity-based social movements ... of the twentieth century."); Robert C. Post \& Reva B. Siegel, Legislative Constitutionalism and Section Five Power:

Policentric Interpretation of the Family and Medical Leave Act, 112 Yale L.J. 1943, 1945 (2003) (arguing Section 5 of the Fourteenth Amendment "links the legal interpretations of courts to the constitutional understandings of the American people"); Reva B. Siegel, Constitutional Culture, Social Movement Conflict and Constitutional Change: The Case of the de facto ERA, 94 Cal. L. Rev. 1323, 132325 (2006) (arguing expansion of the Fourteenth Amendment's Equal Protection Clause to cover sex discrimination "was forged in the Equal Rights Amendment's defeat").

${ }^{194}$ See Eskridge \& Ferejohn, supra note 87, ch. 1, at 9, (emphasizing need to add consideration of central role played by agencies in constitutional development and noting "administrative constitutionalism ... is the primary means by which social movements interact with the state"); see also Lee, supra note 88 , at 66 (arguing that popular mobilizations, such as letter-writing campaigns, are important in spurring administrative constitutionalism). 
regularly consult with interest groups and receive data and filings from members of the public urging a particular course of action on the government. Moreover, unlike Congress or the President, agencies are held to a duty to consider and respond to the information submitted to them in setting policy - a duty enforced by the courts through ordinary administrative law doctrines such as hard look review. As a result, administrative proceedings also can be occasions in which to initiate popular discussion and deliberation about what the Constitution requires and how constitutional demands should be met. ${ }^{195}$ These understandings may then form an occasion for beneficial dialogue with the courts - and perhaps with Congress and the President - about how the Constitution itself should be understood.

3. Preserving Political Branch Prerogatives. - Perhaps the most powerful criticism of using ordinary administrative law to encourage administrative constitutionalism is the fear that doing so will sanction expanded judicial interference in administrative decisionmaking. Scholars already attack arbitrary and capricious review as impeding agencies' ability to function ${ }^{196}$ and as strongly affected by judicial political biases. ${ }^{197}$ Adding the ability to reverse agency decisions for inadequately considering relevant constitutional concerns might seem to risk even greater judicial intrusion into policy choices that should be left to agencies and their political overseers.

${ }^{195}$ Eskridge \& Ferejohn, supra note 87, intro., at 12 ("[Administrative constitutionalism] is more mobile in responding to important social movements and social needs, addresses its vision and commands to all Americans and not just government officials, and creates positive structures and affirmative rights ... to assure opportunities for personal flourishing ... ."); cf. Mark Seidenfeld, A Civic Republican Justification for the Bureaucratic State, 105 Harv. L. Rev. 1511, 1515 (1992) ("Although the Congress, the President, and the courts retain an important reviewing function, having administrative agencies set government policy provides the best hope of implementing civic republicanism's call for deliberative decisionmaking informed by the values of the entire polity.").

${ }^{196}$ See supra sources cited in note 40

${ }^{197}$ See, e.g., Thomas J. Miles \& Cass R. Sunstein, The Real World of Arbitrariness Review, 75 U. Chi. L. Rev. 761, 767-69 (2008) (finding "significant evidence of a role for judicial ideology in judicial review of agency decisions for arbitrariness"). 
The potential for expanded judicial intervention certainly exists under the ordinary administrative law approach. But such intervention is not necessarily illegitimate; instead, I have sought to argue here that it is an appropriate consequence of recognizing agencies' obligations to take constitutional concerns seriously. ${ }^{198}$ Regardless, any assessment of the appropriateness of enforcing constitutional norms through ordinary administrative law must take account of the alternatives. One possibility is, of course, that the Court will restrict itself to only assessing whether the administrative action at issue is actually unconstitutional, as the Fox majority advocated. ${ }^{199}$ Although that option might appear to leave more room to agencies to exercise the policymaking discretion delegated to them by Congress, its actual effect might be quite the opposite. Direct judicial constitutional enforcement may yield requirements that offer less flexibility to the political branches in structuring government programs and policies. A standard argument made in constitutional common law's defense is that forcing courts to definitively articulate the contours of constitutional rights and requirements risks "improvident constitutionalization" and "imposing an inflexible regime upon Congress and the states. ${ }^{200}$ Constitutional common law, by contrast, allows "pressures for change [to] be accommodated either by legislation or by an open reconsideration of the subconstitutional policy concerns underlying an initial formulation of the rule. ${ }^{1201}$ Preserving the political branches' flexibility in constructing administrative arrangements also supports judicial efforts to develop ordinary administrative law doctrines to address constitutional concerns, such as the reasoned decisionmaking

${ }^{198}$ See supra Part II.B.1.

${ }^{199}$ See FCC v. Fox Television Stations, Inc., 129 S. Ct. 1800,1812 (2009)

("We think [unlawfulness] is the only context in which constitutionality bears upon judicial review of agency action.").

${ }^{200}$ Meltzer, supra note 149 , at 1173.

${ }^{201}$ Monaghan, Constitutional Common Law, supra note 1, at 28. An example from the privatization context can help make this point more concrete: Requiring that legislatures or agencies create adequate mechanisms to oversee and ensure accountability of private contractors as a constitutional condition of privatizing limits the political branches' flexibility to structure privatization arrangements as they see fit, but it is less restrictive than the alternative of making the government's private partners directly subject to constitutional demands. Metzger, Privatization as Delegation, supra note 162, at 1457-61. 
requirement, rather than imposing hard and fast constitutional demands.

Even Fox acknowledged, moreover, that one likely alternative to requiring that agencies take constitutional concerns into account will be judicial enforcement of those concerns through the mechanism of the constitutional canons, in particular the canon of constitutional avoidance. ${ }^{202}$ Much recent scholarship on the constitutional canons has argued that, despite their seemingly milder appearance, decisions applying the canons can be as intrusive on Congress - indeed, perhaps more so - as decisions holding statutes to be unconstitutional. ${ }^{203}$ If these canons are in fact doing any work, then they are yielding statutory interpretations different from the reading that would otherwise obtain. ${ }^{204}$ The effect is to trump the political compromise that initially underlay enactment of the measure; worse, the courts' interpretations may change political dynamics in a way that precludes easy enactment of clarifying or reversing legislation by Congress. ${ }^{205}$ Whether or not the formal possibility of congressional reenactment deserves more weight in the equation than these arguments allow, ${ }^{206}$ it is hard to dispute that application of the canons

${ }^{202}$ Fox, 129 S. Ct. at 1812 n.3.

${ }^{203}$ See Schauer, supra note 138 , at 74 ("It is by no means clear that a strained interpretation of a federal statute that avoids a constitutional question is any less a judicial intrusion than the judicial invalidation on constitutional grounds of a less strained interpretation of the same statute."); see also Manning, Nondelegation, supra note 61, at 228 (arguing constitutional avoidance canon upsets legislative compromises and results in legislative outcomes that may not have been obtainable ex ante).

${ }^{204}$ See Schauer, supra note 138 , at 87,89 (stating effect of constitutional avoidance is to supplant "a judge's or court's preconstitutional views about how a statute should be interpreted" and characterizing avoidance as "superfluous" if it "leads only to the same result that the interpreter would have reached without even considering the relevance of the Constitution").

${ }^{205}$ See Jerry L. Mashaw, Greed, Chaos, and Governance 102-03, 105 (1999) (arguing that an interpretation that avoids constitutional problems is "likely to be different from what the court thinks the legislature intended" and probably "uncorrectable" by the legislature); Manning, Nondelegation, supra note 61, at 254 55 (discussing avoidance's cost to legislative will and stating "the avoidance canon may enshrine a result that could not have been adopted ex ante").

${ }^{206}$ See Metzger, New Federalism, supra note 60, at 2093-94 ("Clear statement and other process requirements can pose real obstacles for Congress ... [but] Congress at least retains the option of reenactment."); see also Manning, Clear 
can prove a substantial obstacle for Congress, given the difficulties involved in getting federal legislation enacted.

Administrative agencies, however, can respond to judicial reversal more easily than Congress. In part this is because, burdensome though administrative procedures can be, they do not involve the same types of "vetogates" entailed in getting legislation through Congress and signed by the President. ${ }^{207}$ Further, reversal of an agency decision on ordinary administrative law grounds generally results in a remand to the agency; this is the standard course, for example, when a court sets aside an agency determination as arbitrary and capricious. ${ }^{208}$ As a result, the agency usually has to act in order to have the rule or decision in question take effect, ${ }^{209}$ and does not confront the situation Congress may face after application of the canon of constitutional avoidance: continuation of the challenged statute in a significantly altered form, but without the political coalition to enact an override of the court's decision. Moreover, although formulation of rules and agency decisions may involve negotiation among many agency personnel, they all at least ostensibly share the goal of formulating the best policy from the agency's perspective - and in the end, the agency head generally wields decisionmaking authority. Thus, a partial remand of an agency decision does not pose the same danger of overturning careful political compromises as does application of the canon of avoidance.

An additional important advantage that agencies offer is their deep knowledge of the substantive fields they regulate and the federal

Statement Rules, supra note 137, at 403-05 (explaining why "clear statement rules almost surely intrude less than would Marbury-style judicial review").

${ }^{207}$ See Metzger, New Federalism, supra note 60, at 2090 (noting the greater ease with which administrative agencies can adopt policies compared to Congress and underscoring that "raising federalism concerns through the administrative law rubric does not erect a permanent barrier to federal administrative action; instead ... [it] rather results in a remand for further administrative consideration"). For a description of the vetogates involved in enacting federal statutes, see William N. Eskridge, Jr., Vetogates, Chevron, Preemption, 83 Notre Dame L. Rev. 1441, 144448 (2008) (discussing multiple opportunities where members of House or Senate can kill proposed legislation).

2083 Pierce, Administrative Law Treatise, supra note 117, § 18.1, at 1323.

${ }^{209}$ Even when a court grants remand without vacatur, the agency knows it must eventually respond or face vacatur in the future. See $1 \mathrm{id} . \S 7.13$, at 522 . 
regulatory schemes in question. ${ }^{210}$ This substantive expertise means that agencies are better equipped than courts to determine how to incorporate constitutional values and norms with the least disruption to federal regulatory schemes. Courts may have greater understanding and appreciation of constitutional values and principles in general, but they are less competent in balancing constitutional and policy concerns at a more granular level. ${ }^{211}$ Often several options will exist through which to address the constitutional concerns raised by a statute or agency action. Rapanos v. United States provides a recent illustration. That case involved the scope of federal regulation of intrastate wetlands and the concern that such regulation might exceed constitutional limits on federal power. A number of different regulatory approaches could address this danger. Two were suggested by the plurality and concurrence, respectively: regulating only permanent bodies of water with a continuous connection to waters of the United States, ${ }^{212}$ or undertaking a caseby-case assessment of whether a particular wetland has a "significant nexus" to traditional navigable waters. ${ }^{213}$ But other approaches were also available, such as exempting any wetlands and tributaries not clearly navigable waters in their own right, or creating a rebuttable presumption that wetlands adjacent to navigable waters or their tributaries are subject to regulation. The federal agencies statutorily charged with implementing the Clean Water Act have the factual and policy expertise needed to determine which of these possibilities best achieves federal water pollution goals while respecting state authority. ${ }^{214}$ Those agencies' greater political accountability

${ }^{210}$ Cf. Wyeth v. Levine, 129 S. Ct. 1187, 1201 (2009) ("While agencies have no special authority to pronounce on pre-emption absent delegation by Congress, they do have a unique understanding of the statutes they administer and an attendant ability to make informed determinations about [the impact of] ... state requirements.").

${ }^{211}$ See Metzger, New Federalism, supra note 60, at 2081-83 (discussing relative expertise of federal agencies and federal courts).

${ }^{212}$ Rapanos v. United States, 547 U.S. 715, 739, 742 (2006) (plurality opinion).

${ }^{213}$ Id. at 779 (Kennedy, J., concurring in the judgment).

${ }^{214}$ See Bamberger, supra note 73, at 96-97 (arguing agencies may have a "unique vantage" point for understanding constitutional implications of a federal regulatory scheme); Metzger, New Federalism, supra note 60, at 2082-83 ("Agencies likely will have greatest expertise on the specific question of how best 
compared to courts also means that both the President and Congress will have more openings for influencing this policy choice when undertaken in an administrative context. ${ }^{215}$

\section{The Need for Greater Transparency}

In sum, using ordinary administrative law to encourage administrative constitutionalism not only accords with our constitutional structure and modern administrative reality, but also represents an important tool for ensuring constitutional enforcement while also respecting political branch prerogatives. For this approach to reap its hypothesized rewards, however, the Court must be open about the relationship between constitutional law and ordinary administrative law. Otherwise, agencies and courts will lack a clear understanding of agencies' obligation to take constitutional concerns into account, with underexploitation of administrative capacity to address constitutional concerns the likely result.

Lack of transparency, unfortunately, is one of the defining hallmarks of the Court's precedent in this area. Not only has the Court not overtly developed ordinary administrative law into a tool for constitutional enforcement, it has largely failed to identify the constitutional concerns underlying its development of ordinary administrative law doctrines. This marks a significant difference between the Court's use of ordinary administrative law to address constitutional concerns and its application of the constitutional canons. Critics of the canon of constitutional avoidance frequently take the Court to task for failing to deeply engage with the constitutional concerns leading to the canon's application. But the

to balance federal-state regulatory roles."); see also Brian Galle \& Mark Seidenfeld, Administrative Law's Federalism: Preemption, Delegation, and Agencies at the Edge of Federal Power, 57 Duke L.J. 1933, 1948-83 (2008) (offering detailed comparison of comparative institutional strengths of Congress, courts, and agencies, focusing on preemption issues); Thomas W. Merrill, Preemption and Institutional Choice, 102 Nw. U. L. Rev. 727, 753-59 (2008) (same).

${ }^{215}$ See Bamberger, supra note 73, at 97-100 (discussing ways agency decisionmaking can "facilitate political oversight"); see also Metzger, New Federalism, supra note 60 , at 2083-86 (discussing how procedural requirements can enhance congressional as well as state and local input into federal administrative decisions with federalism implications). 
Court at least identifies the constitutional question at issue and states expressly that constitutional concerns are playing a role in its statutory analysis. ${ }^{216}$ The Court is similarly overt when it applies constitutionally derived clear statement rules or presumptions. ${ }^{217}$ Even that degree of transparency is absent in the Court's development of ordinary administrative law.

To be sure, greater judicial candor and transparency can come at a price. A court's greater honesty about the concerns motivating its decisions may reveal unpalatable value choices, raise obstacles to securing the agreement of multimember bodies, or have worrying implications for future decisions. ${ }^{218}$ Candor and transparency can also preclude certain results. As suggested earlier, the Court's current silence likely reflects its discomfort with independent federal court lawmaking when not constitutionally mandated, combined with its insistence on judicial supremacy within the constitutional sphere. ${ }^{219}$ Perhaps the Court would not be willing to keep developing ordinary administrative law as it has and would pull back from current doctrines if forced to confront the extent to which ordinary administrative law may be at odds with this understanding of the

${ }^{216}$ See, e.g., Nw. Austin Mun. Util. Dist. No. One v. Holder, 129 S. Ct. 2504, 2512-13 (2009) (noting potential constitutional tension and interpreting statute to avoid it); United States v. X-Citement Video, Inc., 513 U.S. 64, 78 (1994) (same).

${ }^{217}$ See, e.g., Wyeth v. Levine, 129 S. Ct. 1187, 1194-95 (2009) (stating presumption against preemption); Gregory v. Ashcroft, 501 U.S. 452, 460-64 (1991) (applying clear statement rule when legislation alters federal-state balance).

${ }^{218}$ See, e.g., Guido Calabresi \& Philip Bobbitt, Tragic Choices 26-28, 78-79, 195-97 (1978) (arguing it is honesty that reveals the "tragic choice" between conflicting values, and that "evasion [and] disguise" can conceal any value choices made); Scott C. Idleman, A Prudential Theory of Judicial Candor, 73 Tex. L. Rev. 1307, 1381-95 (1995) (discussing practical and normative factors weighing against judicial candor). But see Micah Schwartzman, Judicial Sincerity, $94 \mathrm{Va}$. L. Rev. 987, 990-91 (2008) (arguing judicial sincerity about grounds of decisions is necessary for judges to fulfill demands of the judicial role). Moreover, insofar as judges are not aware of the forces motivating their decisions, greater transparency may not be easily possible. See Nicholas S. Zeppos, Judicial Candor and Statutory Interpretation, 78 Geo. L.J. 353, 408 (1989) ("When the instantaneous nature of interpretation shrouds the reasons for the decision, it is hard to fault the court for not being candid.").

${ }^{219}$ See supra text accompanying notes 96-98 (discussing possible reasons for the Court's reluctance to acknowledge constitutional concerns in development of administrative law). 
proper bounds of the judicial role. ${ }^{220}$ My own view, however, is that such a pullback is unlikely; the constitutional concerns raised by the possibility of broad and unconstrained agency power run too deep.

More importantly, the Court's lack of transparency about the constitutional dimensions of ordinary administrative law has significant costs as well - costs that go beyond simply failing to exploit the beneficial potential of administrative constitutionalism. Of greatest concern, lack of transparency is a serious impediment to both judicial and administrative accountability. ${ }^{221}$ The constitutional underpinnings of ordinary administrative law doctrines have remained largely undeveloped and untested by criticism. We have little understanding of the extent to which agency explanation and reasoning are constitutionally necessary conditions for delegation, or of the basis on which such constitutional requirements can be justified. Critiques of current hard look review, meanwhile, are incomplete insofar as they target only the doctrine's statutory basis or pragmatic implications without also assessing its putative constitutional basis. Lack of judicial transparency also impedes administrative accountability; not only are the courts less willing to probe how constitutional concerns factored into agency deliberations, but agencies themselves have little incentive to identify and justify the influence such concerns had on their decisionmaking. This worsens the accountability risks associated with administrative constitutionalism, as it becomes much harder for the public, Congress, and the courts to police agency constitutional reasoning and ensure that agencies do not base their decisions on insubstantial constitutional concerns. To my mind, these potential gains of greater judicial candor outweigh its possible harms.

${ }^{220}$ See Zeppos, supra note 218, at 404-05 (arguing requirement of candor may prevent courts from serving a checking function).

${ }^{221}$ Another possible effect, if the Court reviews agency action searchingly out of constitutional concerns but does not state so openly, may be enhanced lower court scrutiny of administrative action across the board, resulting in unnecessary intrusion on administrative decisionmaking when constitutional factors are not in play. See Metzger, New Federalism, supra note 60, at 2108-09 ("From an administrative law perspective, the danger is that these more extreme approaches [with courts applying more searching scrutiny] will spill over into contexts in which federalism concerns are absent."). 


\section{CONCLUSION}

The time has therefore come for the Court to be forthright about the constitutional character of ordinary administrative law. The linkages between constitutional law and ordinary administrative law are not only diverse, they are longstanding and deeply rooted in current doctrine. Segregating constitutional law and administrative law would thus prove quite difficult and disruptive. Worse, it would forgo the significant benefits to be gained from encouraging administrative agencies to take constitutional concerns seriously in their decisionmaking. Rather than clinging to a false divide between constitutional law and ordinary administrative law, the Court would do better to embrace this linkage and acknowledge the important role that administrative agencies can and do play in the development of constitutional law. 